\title{
Positron Emission Tomography-Based Response to Target and Immunotherapies in Oncology
}

\author{
Maria Isabella Donegani ${ }^{1,2}$, Giulia Ferrarazzo ${ }^{1,2}$, Stefano Marra ${ }^{1,2}$, Alberto Miceli ${ }^{1,2}$, \\ Stefano Raffa ${ }^{1,2}$, Matteo Bauckneht ${ }^{1,2}$ (1) and Silvia Morbelli ${ }^{1,2, *}$ \\ 1 Nuclear Medicine Unit, Department of Health SciencesUniversity of Genoa, 16132 Genoa, Italy; \\ isabella.donegani@gmail.com (M.I.D.); giulia.ferrarazzo@gmail.com (G.F.); marra_ste_pio@yahoo.it (S.M.); \\ albertomiceli23@gmail.com (A.M.); Stefanoraffa@live.com (S.R.); matteo.bauckneht@gmail.com (M.B.) \\ 2 IRCCS Ospedale Policlinico San Martino, 16132 Genoa, Italy \\ * Correspondence: silviadaniela.morbelli@hsanmartino.it; Tel.: +39-010-555-4810; Fax: +39-010-555-6911
}

Received: 15 June 2020; Accepted: 21 July 2020; Published: 24 July 2020

\begin{abstract}
F}\right]$ fluoro-D-glucose ( $\left.\left[{ }^{18} \mathrm{~F}\right] \mathrm{FDG}\right)$ is a promising tool to support the evaluation of response to either target therapies or immunotherapy with immune checkpoint inhibitors both in clinical trials and, in selected patients, at the single patient's level. The present review aims to discuss available evidence related to the use of [ ${ }^{18}$ F]FDG PET (Positron Emission Tomography) to evaluate the response to target therapies and immune checkpoint inhibitors. Criteria proposed for the standardization of the definition of the PET-based response and complementary value with respect to morphological imaging are commented on. The use of PET-based assessment of the response through metabolic pathways other than glucose metabolism is also relevant in the framework of personalized cancer treatment. A brief discussion of the preliminary evidence for the use of non-FDG PET tracers in the evaluation of the response to new therapies is also provided.
\end{abstract}

Keywords: positron emission tomography; target therapy; immunotherapy; response assessment; PERCIST criteria

\section{Introduction}

For several decades, cytotoxic chemotherapeutic agents were considered the basis of anticancer treatment for patients with metastatic tumors. Recently, the discovery of molecular origins of tumorigenesis led to the introduction and transition to the clinics of novel agents aiming to target and inhibit signal transduction [1]. By focusing on molecular abnormalities, specific to cancer cells, target cancer therapies have the potential to be more effective against cancer and often less harmful to normal cells than conventional chemotherapeutics [2]. For several reasons, the introduction of these novel types of treatment has been associated to an increased need of predicting patients' prognosis since baseline evaluation and early capture of the response after initiating therapy. As, especially in patients treated with therapies interfering with signal transduction, these features are strictly related to cancer biology, and functional imaging (Positron Emission Tomography (PET) and magnetic resonance imaging (MRI)) has shown high potential to bring new perspectives in this field especially in terms of response evaluation. In fact, in the frame of target therapies, anatomical response criteria based on the measurement of tumor size by means of computed tomography (CT) might be not able to fully capture viable tumor reduction, thus hampering an early differentiation to responders and non-responders. Moreover, the ongoing revolution in cancer treatment has been unfortunately associated with relevant aggregate costs in terms of cancer care in the last decades [3].

Studies published in the last 10 years have suggested that changes in terms of tumor glucose metabolism as assessed by means of 2-deoxy-2-[ $\left.{ }^{18} \mathrm{~F}\right]$ fluoro-D-glucose ([ $\left.\left.{ }^{18} \mathrm{~F}\right] \mathrm{FDG}\right)$ PET can predict pathologic response rates and patients' outcomes early in several cancer types and preclinical models [4]. 
In more recent years, the need to tell part responders and non-responders early to limit both toxicity and an unnecessary burden to healthcare systems has become even more prominent after the introduction of compounds targeting intracellular negative regulators, such as immune checkpoint inhibitors (ICPIs) [5]. ICPIs have demonstrated powerful antitumor activity across a wide range of solid tumors [5]. In fact, in parallel with the meaningful effects on patients' outcome, the hyperactivation of immune systems triggered by immunotherapy has resulted in a wide range of immune-related side effects, triggering inflammatory reactions [6]. Consequently, the radiological effect of immunotherapeutic agents has raised even more relevant and complex challenges for the determination of the imaging-based response at the single patient level [7].

PET technology might be a useful tool to support the evaluation of response to either target therapies or ICPIs both in clinical trials and at the single patients' level; however, several points still need to be addressed to validate the use of PET evaluation in these settings.

The present review aims to summarize and comment on the available evidence related to the use of 2-deoxy-2-[ ${ }^{18}$ F]fluoro-D-glucose ([ $\left[{ }^{18} \mathrm{~F}\right]$ FDG) PET to evaluate the response to target therapies and ICPIs. Methodological aspects, proposed criteria, as well as its potential added value with respect to morphological imaging are also addressed. Finally, the capability of PET technology to explore several metabolic pathways beyond glucose metabolism is of great potential interest in the field of personalized cancer treatment. Accordingly, a brief discussion of the preliminary evidence for the use of non-FDG PET tracers in the evaluation of response to new therapies is also provided.

\section{From Tumor Shrinkage to Metabolic Response in Oncoematology: Methodological Overview}

The World Health Organization (WHO) criteria were the first radiological criteria introduced into clinical and trial practice to evaluate the dimensional response of solid tumors to cytotoxic therapies [8]. In 2000, the Response Evaluation Criteria in Solid Tumors (RECIST) criteria were also developed, subsequently updated to RECIST v1.1, and are currently widely used [9,10]. WHO and RECIST are standardized and repeatable guidelines based on the quantitative evaluation of tumor size and the number of lesions, and changes on morphological images (CT or MRI). Both systems, by means of bi- and unidimensional measurements, respectively, aim to objectively identify four categories of anatomical responses: Complete response (CR), partial response (PR), stable disease (SD), and progressive disease (PD). The main recognized limits of these methods are related to the challenge of distinguishing and delineating an "active" tumor lesion (viable tissue) from secondary changes (i.e., fibrotic tissue). Moreover, the use of anatomic imaging is suboptimal for tumors that do not change in size early during therapy. Accordingly, these criteria have relevant limits in the evaluation of the response in patients treated with therapies that mainly have a cytostatic effect, such as target therapies [11].

Metabolic imaging with $\left[{ }^{18} \mathrm{~F}\right] \mathrm{FDG}$ PET and PET/CT has thus become increasingly used to provide biologically relevant information with high prognostic value [12]. The rationale is based on the characteristic strong correlation between [ $\left.{ }^{18} \mathrm{~F}\right]$ FDG PET uptake and the number of viable cancer cells in many tumors, which has been observed to decrease early in responders both to "standard" chemotherapy and target therapies [13]. Although $\left[{ }^{18} \mathrm{~F}\right] \mathrm{FDG}$ PET is an inherently "quantitative" method potentially providing data on tumor glucose metabolic levels, for a relatively long time, only a binary evaluation based on visual inspection has been used to assess the PET-based tumor response.

The first proposal for objective PET-based response criteria, the EORTC (European Organization for Research and treatment for Cancer) criteria, was published in 1999. The EORTC metabolic criteria have the historical merit of having conceived the idea of a quantitative (objective) evaluation of the images, going over the visual qualitative one. The EORTC criteria were originally based on the assumption that an early metabolic response can be assessed when anatomical change is not visible yet. The EORTC criteria are based on measurement of the so-called mean standardized uptake value (SUVmean). SUV is defined as the ratio of activity per unit volume of a region of interest (ROI) to the activity per unit whole body volume. SUV aimed to quantify $\left[{ }^{18}\right.$ F]FDG PET uptake in a semiquantitative way 
as opposed to true quantification through compartmental and kinetic modeling [13]. However, SUV is influenced by multiple factors (not related to the biological characteristics of the tumor or to the patient's response), such as the uptake time (time between tracer injection and image acquisition), the patient's glucose levels and body weight, and the dimensions of the lesions and ROIs definition. Accordingly, the EORTC working group has also produced a list of valid recommendations to improve the quality and better standardize $\left[{ }^{18}\right.$ F]FDG PET imaging, thus increasing the standardization of SUV measurement before and after therapy. Nonetheless, for its limits, mostly given to the limited data available at the time, the EORTC criteria have never routinely entered the clinical practice nor were routinely incorporated in clinical trials [12,13].

\subsection{Metabolic Response in Solid Tumors}

In 2009, the PET response criteria in solid tumors (PERCIST) criteria were proposed with the intent of improving the standardization of the PET-based response in oncology. One of the main changes introduced with the PERCIST criteria was the correction of SUV for lean body mass (SUL). This correction aimed to avoid possible effects of SUV measurements due to weight loss occurring during the course of therapy. Moreover, to overcome issues related to the definition and size of ROIs, the PERCIST criteria introduced the use of SULpeak, which is defined after drawing a small standard dimension (a sphere of a $1.2 \mathrm{~cm}$ diameter) around the maximal pixel. In fact, SULpeak has the advantage of less statistical variance compared to the single pixel (SUVmax), especially in noisy images. The single hottest tumor lesion then became the target lesion (later on increased to include up to five target lesions before and after therapy).

PERCIST has been demonstrated to be a strong predictor of outcomes and more effective than RECIST in distinguishing responders from non-responders after neoadjuvant chemotherapy in patients treated for esophageal cancer [14-16]. Similarly, in advanced non-small-cell lung cancer (NSCLC), after the first cycle of chemotherapy, an $\left.{ }^{18} \mathrm{~F}\right] \mathrm{FDG}$ uptake reduction was demonstrated to strictly correlate with the time to progression and overall survival (significantly longer for metabolic responders than for non-responders) [17]. In a trial directly comparing PERCIST and RECIST criteria, $\left[{ }^{18}\right.$ F]FDG PET turned out to be more sensitive in detecting CR and progressions in NSCLC patients who received chemotherapy $[18,19]$. However, PERCIST's usefulness and advantages over the morphologic criteria still need to be further addressed [14]. Currently, neither EORTC nor PERCIST are used in the daily clinical reporting. Similarly, a supremacy of one over the other has never been demonstrated. Few studies have compared the two PET-based metabolic criteria, generally demonstrating good agreement between the EORTC and PERCIST criteria in evaluating treatment response to solid malignant tumors [20]. The definition of group response based on the EORTC and PERCIST criteria follows the historical classification of the RECIST criteria in terms of a partial and complete response, and stable or progressive disease. These group responses are thus based on variations in terms of tumor metabolism, thus defined as a partial metabolic response, stable metabolic disease, or progressive metabolic disease.

In more recent years, other indicators of cancer-related metabolic activity have been introduced: Metabolic tumor volume (MTV) and total lesion glycolysis (TLG). MTV is a biomarker defined as the volume of tumor tissue that exhibits FDG uptakes above a set SUV threshold [21]. More frequently, two thresholds have been proposed based on iso-counting of the volume of the lesion above $40 \%$ of the SUVmax or above a fixed cut-off (generally SUV 2.5) [21]. TLG is the product of MTV and SUVmean, and represents the total activity of all metabolically active cancer cells. These volume-based metrics have the advantage of assessing data from the entire tumor, while the SUVmax or SUVpeak only assess the most active part. On the other hand, both parameters depend on the SUV and therefore are subject to the same limits [22]. Several studies have evaluated the correlation between these parameters and some survival outcomes in different neoplasms. MTV appeared to be superior to SUVmax as a prognostic factor in the overall survival (OS) of patients treated with SBRT in early NSCLC [23]. TLG values were significantly correlated with tumor thickness, depth of invasion, and clinical stage of head and neck cancers and showed a correlation with OS and the presence of distance metastasis [24]. 
Finally, MTV and TLG demonstrated an early ability to predict OS in patients with colorectal liver metastases post-radioembolization, showing how these parameters can also be used in the assessment of new radiometabolic therapies [22].

\subsection{Metabolic Response in Lymphomas}

While use of the PET-based response is promising but not yet incorporated in clinical practice for patients with solid tumors, the metabolic response has been fully validated for both clinical settings and trial use in patients with Hodgkin's and non-Hodgkin's lymphomas (HL and NHL).

In fact, the use of CT for assessing response to therapy in HL and NHL suffers from the same limitation described for solid tumors. The CT-based response is hampered by the impossibility to distinguish the presence of fibrosis/necrosis from active neoplastic tissue. In patients with lymphomas, an extensive body of literature has demonstrated the predictive value of the response to treatment both in the early and final evaluation. Given the high predictive value of PET in these specific clinical settings, several criteria have been proposed to standardize response evaluation in patients with HL and NHL both at the interim evaluation and at the end of therapy.

In 2009, the Deauville criteria were fully validated to analyze interim and end-of-treatment PET scans. The Deauville score is based on a visual qualitative scale obtained through the comparison between the lesion's residual uptake (if any) and the uptake in reference regions (mediastinal blood pool and liver), allowing classification of the residual uptake based on a 5-point scale from 1 (i.e., no uptake) to 5 (i.e., uptake higher than the liver). This criterion was indeed designed to improve the standardization by eliminating the concept of SUV and increasing concordance among readers. $\left[{ }^{18} \mathrm{~F}\right] \mathrm{FDG}$ PET/CT is currently considered an effective biomarker of lymphomas, and DS criteria became a gold standard included in the Lugano guidelines for the management of the disease as it gives clear clinical information with objectivity and reproducibility [25]. According to the Lugano criteria, the Deauville points match with different types of metabolic response based also on the comparison between baseline and post-therapy scans [26]. [ $\left.{ }^{18} \mathrm{~F}\right] \mathrm{FDG}$ PET/CT is now the modality of choice for monitoring and for tailoring response-adapted treatment strategies both for early assessment during therapy (interim PET) and at the end of therapy $[27,28]$. Group responses based on the RECIST, EORTC, PERCIST, and Lugano criteria are reported in Table 1.

In conclusion, $\left[{ }^{18} \mathrm{~F}\right] \mathrm{FDG}$ PET, a widely available tool for imaging both in solid tumor and lymphomas, has showed a promising capability to capture early and atypical patterns of response that might also represent targets to predict response to new therapies. 
Table 1. A schematic summary of the class of response according to RECIST 1.1, EORTC, PERCIST, and Lugano criteria.

\begin{tabular}{|c|c|c|c|c|}
\hline Category & RECIST 1.1 & EORTC (1999) & PERCIST & LUGANO \\
\hline Target lesion & Up 2 per organs, maximum 5 in total & $\begin{array}{c}\text { The most }\left[{ }^{18} \mathrm{~F}\right] \mathrm{FDG} \text { avid lesions (SUV } \\
\text { BSA). } \\
\text { Number of lesions not specified }\end{array}$ & $\begin{array}{l}\text { The hottest single tumor lesion at } \\
\text { baseline }\left[{ }^{18} \text { F]FDG PET (SUL peak) }\right.\end{array}$ & $\begin{array}{l}\text { - Up to } 6 \text { measurable nodal }(\mathrm{LDi}>1.5 \mathrm{~cm} \text { ) } \\
\text { and extranodal sites (LDi }>1 \mathrm{~cm}) \\
\text { Non-measurable disease sites LDi }>1.5 \\
\mathrm{~cm} \mathrm{LDi}>1.0 \mathrm{~cm} \text { All other disease sites } \\
\text { nodal/extranodal/assessable disease } \\
\text { (skin, GI, bone, spleen, liver, } \\
\text { kidneys, effusions) }\end{array}$ \\
\hline New lesion & \multicolumn{4}{|c|}{ Any new lesion results in progressive disease at first appearance } \\
\hline Complete response & $\begin{array}{l}\text { - } \begin{array}{l}\text { Disappearance of all target and } \\
\text { non-target lesions }\end{array} \\
\text { - Nodes must regress to }<10 \mathrm{~mm} \\
\text { short axis } \\
\text { - } \\
\text { - } \quad \text { Conew lesions } \\
\text { - }\end{array}$ & Complete absence of $\left[{ }^{18} \mathrm{~F}\right] \mathrm{FDG}$ uptake & $\begin{array}{c}\text { Complete resolution of }\left[{ }^{18} \mathrm{~F}\right] \mathrm{FDG} \text { uptake } \\
\text { within the target lesion }(<\text { mean liver } \\
\text { activity and indistinguishable from } \\
\text { background/blood pool and no new } \\
\left.\left[{ }^{18} \mathrm{~F}\right] \mathrm{FDG} \text { avid lesions }\right)\end{array}$ & $\begin{array}{l}\text { DS 1, 2, and } 3 \\
\text { in nodal or extra-nodal sites, with or without } \\
\text { residual mass }\end{array}$ \\
\hline Partial response & $\begin{array}{l}\text { - } \quad \geq 30 \% \text { decrease in tumor burden } \\
\text { compared to baseline } \\
\text { - Confirmation required }\end{array}$ & A decrease in SUV > 25\% & $\begin{array}{l}\text { A reduction of a minimum of } 30 \% \text { in the } \\
\text { target tumor }\left[{ }^{18} \mathrm{~F}\right] \mathrm{FDG} \text { SUL peak PMR }\end{array}$ & $\begin{array}{l}\text { DS } 4 \text { or } 5 \text { with }\left[{ }^{18} \mathrm{~F}\right] \mathrm{FDG} \text { uptake decreased } \\
\text { compared with baseline }\end{array}$ \\
\hline Progressive disease & $\begin{array}{l}\text { - } \quad \geq 20 \%+5 \mathrm{~mm} \text { absolute increase in } \\
\text { tumor burden compared with nadir } \\
\text { Appearance of new lesions or } \\
\text { progression of non-target lesions }\end{array}$ & $\begin{array}{c}\text { An increase in SUV }>25 \% \text { or appearance } \\
\text { of new lesions }\end{array}$ & $\begin{array}{l}\text { A } 30 \% \text { increase in }\left[{ }^{18} \mathrm{~F}\right] \text { FDG SUL peak or } \\
\text { advent of new }\left[{ }^{18} \mathrm{~F}\right] \mathrm{FDG} \text { avid lesions }\end{array}$ & $\begin{array}{l}\text { DS } 4 \text { or } 5 \text { with an increase in uptake from } \\
\text { baseline \&/or new lesions }\end{array}$ \\
\hline Stable disease & $\begin{array}{l}\text { Neither partial response nor } \\
\text { progressive disease }\end{array}$ & $\begin{array}{l}\text { Increase in SUV by }<25 \% \text { or decrease in } \\
\text { SUV by }<15 \%\end{array}$ & Disease other than CMR, PMR or PMD & DS 4 or 5 with no change in $\left[{ }^{18} \mathrm{~F}\right]$ FDG uptake \\
\hline
\end{tabular}




\section{PET Response to Target Therapies}

The rationale beyond targeted drugs is the inhibition of target proteins that are part of important signal transduction in tumor metabolism, thus interfering with the process of tumor growth, angiogenesis, invasion, and metastasis [4]. Current strategies include antigrowth factor antibodies, receptor antagonists, antireceptor monoclonal antibodies, and small-molecule tyrosine kinase inhibitors. To date, most of these drugs, in addition to having a high economic cost, are only effective in a limited number of patients and are not free from toxicity.

Therefore, it becomes essential to identify non-responding patients early to improve the cost-effectiveness of these new therapeutic strategies and to limit related toxicities [4].

In this context, the anatomical WHO and RECIST criteria have shown multiple limits. As these criteria were originally validated to reflect tumor shrinkage after chemotherapy, they poorly correlate with other types of cancer treatments characterized by a more prominent cytostatic and/or antiangiogenic effect. This challenge has resulted in the need of adapting these criteria and/or formulating new ones more suitable to capture the response to the variegate effect of target therapies.

One of the most relevant and historic examples of target therapies whose radiological response was not suitable for a simple shrinkage-based criterion is represented by gastrointestinal stromal tumors (GISTs) [29]. GISTs are the most common mesenchymal tumors of the gastrointestinal tract. GISTs are treated with imatinib mesylate, a biological antineoplastic drug that works by inhibiting a large number of enzymes with tyrosine kinase activity [30]. It is specific for the tyrosine kinase domain c-kit and PDGF-R, commonly mutated in GIST neoplasms. Imatinib was the first biologic drug created to target a specific protein, and after, its use was approved in unresectable and metastatic GISTs [30]. The introduction of this treatment results in a radical improvement of prognosis and therapeutic outcomes of patients [30]. However, imatinib can result in an increase of the lesion size (i.e., due to intratumoral hemorrhage, necrosis, or myxoid degeneration) associated with a marked reduction of tumor metabolism. For these reasons, it soon became clear that the RECIST criteria were inadequate in the response evaluation. In this framework, the input derived from PET studies showing a lack of or shrinkage (or even increase in tumor volume) was paralleled by a marked reduction in tumor metabolism, which has supported the development of new CT-based criteria. In fact, given the inhibitory activity of these biological drugs on several metabolic pathways, the effect of these drugs on glucose metabolism (one of the main metabolic hallmarks of cancer) was somehow expected [4]. It has been shown that the PI3K/AKT/ mTOR pathway directly regulates glucose metabolism and that it is upregulated in many cancers, due to the overexpression of specific oncogenes. mTOR inhibition with a targeted drug leads to a decrease in glucose uptake. This phenomenon justifies the use of metabolic imaging, as a decrease in $\left[{ }^{18} \mathrm{~F}\right] \mathrm{FDG}$ uptake has been reported on PET scans upon receptor tyrosine kinase and mTOR/PI3K inhibition. The above-mentioned reduction in tumor metabolism is actually associated with a reduction in the density of the lesions (measured as the Hounsfield unit on CT), which is the basis for the criteria developed for the CT-based response in this setting, the so-called Choi criteria. The Choi criteria include not only assessments of the size but also of the density of tumor lesions before and after treatment with imatinib [12]. The response measured with Choi was found to be reproducible, more sensitive, and more precise than RECIST, and was correlated significantly with the time to tumor progression and disease-specific survival [30].

$\left[{ }^{18}\right.$ F]FDG PET based on the PERCIST and EORTC criteria have also been previously used in clinical trials in NSCLC patients treated with kinase inhibitors targeting EGFR, such as Erlotinib and Gefitinib [31,32].

Sunaga et al. monitored Gefitinib treatment in a small population of patients using $\left[{ }^{18} \mathrm{~F}\right] \mathrm{FDG}$ PET PET and reported that an early decrease in lesion tracer uptake is able to predict response. Similarly, Su et al. studied a panel of cell lines with a spectrum of sensitivity to Gefitinib and concluded that $\left[{ }^{18}\right.$ F]FDG PET PET may be a valuable predictor for early response [33]. However, since the tumor can develop secondary mutations of EGFR and other oncogenes, and from the fact that a relevant 
percentage of metastatic locations differs in genetic expression from the primitive disease, predicting tumor responses solely by the presence of specific mutations is not entirely reliable.

A recent trial aimed to determine whether early $\left[{ }^{18} \mathrm{~F}\right]$ FDG PET was able to predict PFS (Progression Free Survival) and OS in unselected patients with advanced NSCLC using PERCIST criteria on a basal scan, compared with an early scan after 2 weeks of treatment. Again, $\left[{ }^{18} \mathrm{~F}\right]$ FDG PET was able to assess changes in tumor $\left[{ }^{18} \mathrm{~F}\right] \mathrm{FDG}$ uptake predicting PFS and OS in a population of unselected patients, allowing customization of the therapeutic approach in the non-responder and avoiding early discontinuation of the therapy in the responder [34].

Finally, another study prospectively evaluated $\left[{ }^{18} \mathrm{~F}\right] \mathrm{FDG}$ PET's role in predicting early response to the neoadjuvant Erlotinib in patients with operable NSCLC. Baseline scans were compared with post-therapy scans acquired as soon as one week of therapy. Patients with a decrease in SUV of $25 \%$ or more after one week were classified as responders according to the EORTC criteria. A comparison with the histopathologic examination of the resected specimen was made, showing a good correlation between the metabolic and the pathological response (the latter expressed as the percentage of necrosis observed). This trial's results supported the concept that early assessment during the course of Erlotinib for NSCLC with $\left[{ }^{18} \mathrm{~F}\right] \mathrm{FDG}$ PET/CT can identify the response in most patients [33].

Finally, a recent study tried to evaluate the performance of $\left[{ }^{18} \mathrm{~F}\right]$ FDG PET in predicting HCC tumor progression during Sorafenib treatment, using as an evaluation parameter the SUV ratio between the most hypermetabolic lesion and the liver in the pretreatment scans. $\left[{ }^{18} \mathrm{~F}\right] \mathrm{FDG}$ PET has been proven to be an independent prognostic factor for survival in patients with HCC receiving Sorafenib, although it may not predict tumor response to the treatment [35].

Despite these several lines of evidence, the true value of $\left[{ }^{18} \mathrm{~F}\right]$ FDG PET after biological targeted therapies needs to be clarified as many questions remain open [36].

First, there is no consensus about the time intervals that should be used for the response evaluation and this timeframe might be significantly influenced by the different targets of signal transduction inhibition as well as by tumor biology. The range reported in the literature in trials carrying out $\left[{ }^{18}\right.$ F]FDG PET-based response evaluation after target therapies ranged from 8 days after therapy [30] to several months after therapy, thus suggesting the potential need to validate the best time-point for response evaluation in different clinical settings. Another relevant issue is the lack of standardization regarding which PET-based criteria (i.e., EORTC, PERCIST criteria) should be used to assess response to therapy. In fact, a large variability is reported in studies involving the use of PET in patients treated with target therapies. Several studies have even reported by means of simple visual-qualitative evaluation of $\left[{ }^{18} \mathrm{~F}\right]$ FDG PET images without the use of semiquantification. Finally, yet importantly, the real negative predictive value of the $\left[{ }^{18} \mathrm{~F}\right] \mathrm{FDG}$ PET response in target therapy still needs to be fully defined, and correlation with PFS or OS should be defined for different compounds and tumors [29]. Moreover, given the well-known limits PET in terms of the spatial resolution, a negative PET scan after therapy in patients with solid tumors treated with target therapies might be due to the low amount of viable cells (falling below the PET spatial resolution). Finally, given the effect on the glucose metabolic pathway of some target therapies, at least in some clinical settings, it might be argued if a reduction of FDG PET uptake reflects an effective response to therapy or rather it simply reflects the initial inhibition in the tumor glucose uptake that might not necessary translate into a true clinical response or might be effective only after a longer period of time. This pathophysiological debate is relevant for the definition of a final link between the PET-based response and improved patients' outcome and survival. Figure 1 shows a representative example of the baseline and post-treatment $\left[{ }^{18} \mathrm{~F}\right] \mathrm{FDG}$ PET scan in a patient with advanced NSCLC treated with Erlotinib. 
(a)

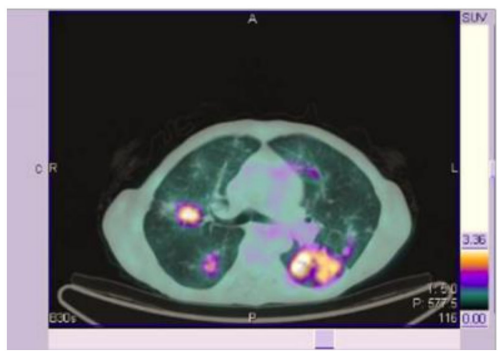

(b)

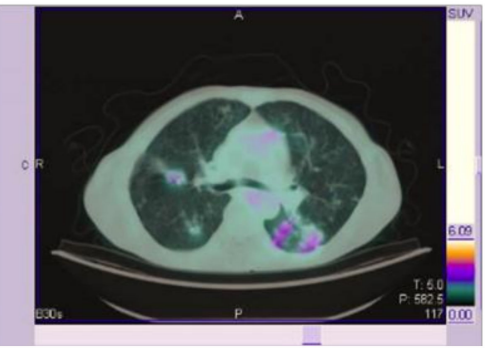

(c)

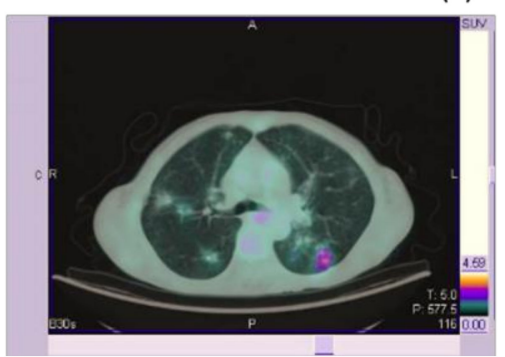

Figure 1. An example of early metabolic response after therapy with Erlotinib in a patient with no smoking history and lung adenocarcinoma. Marked $\left[{ }^{18} \mathrm{~F}\right] \mathrm{FDG}$ uptake is evident at baseline in bilateral lung nodules (SULpeak 7 in the right inferior pulmonary lobe) (a). First response (b) three months after therapy initiation highlights a marked reduction of $\left[{ }^{18} \mathrm{~F}\right] \mathrm{FDG}$ PET uptake in all lung nodules in the absence of a significant reduction in lesion size as evident in the coregistered CT (SULpeak 2 in the right inferior pulmonary lobe, resulting in a partial metabolic response according to the PERCIST criteria while the patient was classified as stable disease according to the RECIST criteria). Nine months after therapy, (c) the metabolic response was still clearly evident and was associated with a measurable reduction also in the lesion size (partial response based also on the RECIST criteria). SUL: Standardized uptake value corrected for the lean body mass; $\left[{ }^{18} \mathrm{~F}\right] \mathrm{FDG}$ : 2-deoxy-2-[ $\left.{ }^{18} \mathrm{~F}\right]$ fluoro-D-glucose; PET: positron emission tomography; CT: computed tomography; RECIST: Response Evaluation Criteria in Solid Tumors.

\section{PET to Response to Immunotherapy}

\subsection{Methodological Issues}

Immunotherapy has recently emerged as an important advance in cancer treatment. It differs from other strategies, especially from conventional chemotherapy, for a shift in the treatment paradigm. In fact, it promotes an activation of the patient's immune response rather than being directly cytotoxic on cancer cells [5,37]. In particular, the activation of the immune system to recognize and kill cancer cells is based on different strategies, such as immunomodulatory monoclonal antibodies, directly enhancing the function of components of the immune response against tumor cells, or blocking immunological checkpoints that would otherwise restrain effective antitumor immunity [5]. Most studied molecules used in immunotherapy belong to the category of ICPIs and are directed against the cytotoxic T lymphocyte-associated protein 4 (CTLA-4), against the programmed cell death protein 1 (PD1) or its complex with programmed cell death protein ligand 1 (PD1/PDL1), which are negative regulators of $\mathrm{T}$ cell immune function [38]. In fact, many cancer types show an increased expression of these molecules. Accordingly, compounds for immunotherapy target these molecules, resulting in a downregulation of inhibitory signals, which determines a global augmented activity in the immune system against the tumor cells. In this framework, Ipilimumab, a CTLA-4 inhibitor, was demonstrated to improve survival rates in melanoma patients [39]. Several PD1/PD-L1 inhibitors have been shown to improve survival rates in patients with different types of tumor, such as lung, melanoma, head and neck, and bladder cancers [40-42]. In parallel with these meaningful effects on patients' outcome, the hyperactivation of immune systems triggered by immunotherapy resulting in a wide range of side effects has been reported, including rash, myalgia, arthritis, enterocolitis, thyroiditis, hypophysitis, and pancreatitis [6]. Similar mechanisms underlie a variegate effect of neoplastic lesions' size and number that might hamper the CT-based evaluation of response to immunotherapy in a subgroup of patients [37].

In particular, one potential challenge in the evaluation of response to ICPIs is represented by the so-called pseudoprogression. This phenomenon consists on an initial increase in the tumor volume and/or number of lesions (due to inflammatory cells' infiltration that mimics cancer progression) followed by the demonstration of tumor shrinkage and a subsequent positive effect in terms of patients' outcome [43]. Pseudoprogression is indeed determined by the activation of the immune system that 
starts to surround the tumor [44]. Pseudoprogression has been reported, especially after therapy with CTLA-4 inhibitors in patients with melanoma [7], and less frequently in other tumor types (possibly in less than $5 \%$ of patients with other diseases, including NSCLC and lymphoma) [43]. Accordingly, if the response is based on the conventional RECIST criteria, these patients may initially meet the conventional response criteria for PD but later might show a reduction in the tumor burden and a final favorable outcome. Accordingly, conventional-based CT has been modified to overcome this limitation by the creation of an immune-related response (irRC) and immune-RECIST criteria $[45,46]$. Actually, in the presence of response-related inflammatory cells' infiltration, patients' assessment based on $\left[{ }^{18} \mathrm{~F}\right]$ FDG PET might also result in findings suggestive of a pseudo (or lack of) response. In fact, one of the most commonly encountered false-positive PET/CT interpretation pitfalls is related to an increased FDG uptake due to inflammation, especially after recent chemo-radiotherapy and/or surgery. Despite the fact that inflammatory infiltration and related tumor changes can also hamper the reliability of the $\left[{ }^{18} \mathrm{~F}\right]$ FDG PET-based response, several studies have to date suggested a potential added value of $\left[{ }^{18} \mathrm{~F}\right]$ FDG PET in a subset of patients [43].

\subsection{PET-Based Response to ICPIs in Patients with Melanoma}

Preliminary experience of the metabolic response to immunotherapy in metastatic melanoma patients was published in 2015 by Sachpekidis and colleagues [47]. This study evaluated the capability of the EORTC response classification to predict patients' outcome after two cycles of treatment with ipilimumab in 22 patients with melanoma. Early PET evaluation was demonstrated to be predictive of late response and of the overall outcome both in patients with stable metabolic disease and patients with progressive metabolic disease.

Moreover, in another study carried out by Kong and colleagues in patients with metastatic melanoma, a measurable metabolic response was able to predict a prolonged response to anti-PD1 treatment [48]. In this study among the 12 patients showing a negative PET scan, 6 were characterized by residual disease at the CT scan and 5 even stopped the treatment but none of them showed recurrence in the 6-10 months of further follow-up. Similarly, Cho and colleagues [46] recruited 20 patients with metastatic melanoma in therapy with either ipilimumab or nivolumab and performed both an early assessment (after 18-21 days) and late assessment (after 4 months) by means of the RECIST, PERCIST, and EORTC criteria in order to define the best matching criteria for PET scan evaluation. While in the early assessment, a low inter-criteria agreement has been reported, late scans resulted in an excellent agreement. In 2017, Amrane et al. aimed to define the best match between morphological and metabolic responses in 20 patients with advanced melanoma treated with ipilimumab $(n=17)$ or nivolumab $(n=3)$ and developed the so-called PECRIT criteria (PET/TC Criteria for Early Prediction of Response to Immune Checkpoint Inhibitor Therapy). Of note this classification introduces the clinical benefit into the definition of response, thus further suggesting that the presence of pseudoprogression might be suspected when radiological progression is paralleled by an evident improvement in the clinical performance status [49]. Immunotherapy-modified PERCIST (imPERCIST) criteria have also been proposed but not yet fully validated in patients with melanoma treated with ipilimumab [50]. According to the imPERCIST criteria, the appearance of new lesions alone did not result in progressive metabolic disease (PMD) and thus, PMD is defined only by an increase of the sum of SULpeaks by $30 \%$. Similarly, new lesions are included in the sum of the SULpeak if they show higher uptake than existing target lesions or if fewer than five target lesions are detected on the baseline scan. Preliminary experience on the imPERCIST criteria is also available in patients with NSCLC treated with Nivolumab.

\subsection{PET-Based Response to ICPIs in Patients with NSCLC}

Rossi and colleagues aimed to compare the evaluation of the first response to Nivolumab by means of CT-based and PET (PERCIST and imPERCIST) criteria in 48 patients with advanced NSCLC [51]. Low concordance was highlighted between the CT- and PET-based criteria (both PERCIST and imPERCIST versus RECIST and irRC, respectively). However, IrRC was more reliable in distinguishing 
responders from non-responders, but, thanks to the prognostic value of the partial metabolic response, the PET-based response maintained prognostic significant in patients classified as progressive disease on the basis of irRC. Taken altogether, these results do not support the routine use of $\left[{ }^{18} \mathrm{~F}\right] \mathrm{FDG}$ PET in the general population of NSCLC patients treated with ICIPs, but they suggest the added prognostic value of the metabolic response assessment, potentially improving therapeutic decision-making.

Interestingly enough, studies have already been performed in order to determine which metabolic criteria could better define the response of HL to immunotherapy; however, no conclusive data are available to date to define which criteria should be used to assess the PET metabolic response in this setting [52]. Finally, given the capability of $\left[{ }^{18} \mathrm{~F}\right] \mathrm{FDG}$ PET/CT to highlight the presence of hypermetabolism related to inflammation, it has also been used to capture the presence of immune-related adverse events (IRAEs) and to correlate them with patients' outcome [53]. PET-detectable IRAE was useful to predict a favorable outcome. In a retrospective study, patients with malignant melanoma, malignant lymphoma, and renal cell carcinoma treated with immunotherapy were evaluated. Patients with IRAE showed a better outcome (with 9 out of 11 patients with IRAE showing a complete response at the final evaluation). On the other side, the potential confounding effect of hypermetabolic lesions due to IRAE should be taken into account when reporting $\left[{ }^{18} \mathrm{~F}\right] \mathrm{FDG}$ PET in patients treated with immunotherapy. Sarcoid-like lung lesions and reactive lymph nodes have been reported and should not be confounded with PMD [53-55]. Similarly, inversion of the liver-to-spleen ratio (normally $>1$ ), reflecting immune activation preceding $\mathrm{T}$ cell proliferation, has been reported [55]. In conclusion, despite the more effective way of assessing the $\left[{ }^{18} \mathrm{~F}\right]$ FDG PET-based response in patients treated with ICPIs, available studies suggest that $\left[{ }^{18} \mathrm{~F}\right] \mathrm{FDG}$ PET can support decision-making about the continuation/discontinuation of therapy, as it can open several windows able to capture different aspects associated with the effect of treatment (i.e., pseudoprogression, hyperprogression, and IRAE) [56]. Table 2 reports the characteristics of published studies involving the use of $\left[{ }^{18} \mathrm{~F}\right]$ FDG PET to assess the response to ICI [46-48,50,51,54,57-68]. Figure 2 shows a representative example of baseline and post-treatment $\left[{ }^{18} \mathrm{~F}\right]$ FDG PET in a patient with advanced NSCLC treated with Nivolumab. 
Table 2. Studies evaluating the role of FDG PET in patients treated with immune checkpoint inhibitors.

\begin{tabular}{|c|c|c|c|c|c|c|}
\hline Reference & Study Type & Patients' Characteristics & Aims & Methods & Results & Conclusions \\
\hline Sachpekidis et al. [47] & prospective & $\begin{array}{l}22 \text { patients suffering from } \\
\text { unresectable metastatic melanoma, } \\
\text { scheduled for ipilimumab } \\
\text { treatment. }\end{array}$ & $\begin{array}{l}\text { To evaluate the role of } \\
\left.{ }^{18} \mathrm{~F}\right] \mathrm{FDG} \text { PET/CT } \\
\text { performed after two } \\
\text { cycles of ipilimumab } \\
\text { in predicting the final } \\
\text { response to therapy. }\end{array}$ & $\begin{array}{l}\text { PET/CT scanning was } \\
\text { performed before the start of } \\
\text { treatment (baseline scan), after } \\
\text { two cycles of treatment (early } \\
\text { response) and at the end of } \\
\text { treatment after four cycles (late } \\
\text { response). Evaluation of the } \\
\text { patient response to treatment } \\
\text { on PET was based on EORTC } \\
\text { criteria. }\end{array}$ & $\begin{array}{l}\text { Early PET/CT performed after } \\
\text { two ipilimumab cycles } \\
\text { predicted treatment response } \\
\text { in } 13 \text { of the } 15 \text { PMD patients, in } \\
\text { five of the five SMD patients } \\
\text { and in neither of the two PMR } \\
\text { patients. }\end{array}$ & $\begin{array}{l}{ }^{18} \text { F]FDG PET/CT after two } \\
\text { cycles of ipilimumab is highly } \\
\text { predictive of the final treatment } \\
\text { outcome in patients with PMD } \\
\text { and SMD. }\end{array}$ \\
\hline Kong et al. [48] & prospective & $\begin{array}{l}27 \text { patients with unresectable stage } \\
\text { IIIC or IV melanoma after } \\
\text { prolonged treatment with } \\
\text { anti-PD-1 antibodies. }\end{array}$ & $\begin{array}{l}\text { To examine the } \\
\text { hypothesis that } \\
\text { patients with } \\
\text { prolonged response to } \\
\text { treatment may have } \\
\text { metabolically inactive } \\
\text { lesions by }{ }^{18} \mathrm{~F} \text { FIFDG } \\
\text { PET/CT. }\end{array}$ & $\begin{array}{c}\text { Scans were performed at a } \\
\text { median of } 15.2 \text { months (range } \\
12-29 \text { months) after starting } \\
\text { treatment. }\end{array}$ & $\begin{array}{l}8 \text { patients with positive scans } \\
\text { underwent biopsy; } 5 \text { of } 8(62 \%) \\
\text { were melanoma and } 3 \text { of } 8 \\
\text { ( } 38 \% \text { ) were immune cell } \\
\text { infiltrates. Of the } 12 \text { patients } \\
\text { with negative }{ }^{18} \text { F]FDG PET } \\
\text { scans, } 6 \text { had residual } \\
\text { computerized } \\
\text { tomography-visible lesions, } 5 \\
\text { have ceased treatment, } \\
\text { and none have recurred with } \\
\text { follow-up of } 6-10 \text { months. }\end{array}$ & $\begin{array}{c}\text { Patients with residual } \\
\text { metastases after a prolonged } \\
\text { period without progression on } \\
\text { anti-PD-1 therapy may have } \\
\text { metabolically inactive lesions. } \\
\text { Isolated metabolically active } \\
\text { lesions in clinically well } \\
\text { patients may reveal immune } \\
\text { cell infiltrates rather than } \\
\text { melanoma. }\end{array}$ \\
\hline Cho et al. [46] & prospective & $\begin{array}{l}20 \text { patients with advanced } \\
\text { melanoma receiving ICIPs. }\end{array}$ & $\begin{array}{l}\left.\text { To evaluate }{ }^{18} \mathrm{~F}\right] \mathrm{FDG} \\
\mathrm{PET} / \mathrm{CT} \text { s canning as } \\
\text { an early predictor of } \\
\text { response to immune } \\
\text { checkpoint inhibitors } \\
\text { in patients with } \\
\text { advanced melanoma. }\end{array}$ & $\begin{array}{l}{\left[{ }^{18} \mathrm{~F}\right] \mathrm{FDG} \text { PET/CT was }} \\
\text { performed at } 3 \text { scan intervals. } \\
\text { Tumor response at each } \\
\text { posttreatment time point was } \\
\text { assessed according to RECIST } \\
1.1, \text { PERCIST } 1.0 \text { and EORTC } \\
\text { criteria. }\end{array}$ & $\begin{array}{l}\text { Early response evaluations } \\
\text { using RECIST 1.1, } \\
\text { immune-related response } \\
\text { criteria, PERCIST, and EORTC } \\
\text { criteria demonstrated } \\
\text { accuracies of } 75 \%, 70 \%, 70 \% \text {, } \\
\text { and } 65 \% \text {, respectively. By } \\
\text { combining early anatomic and } \\
\text { functional imaging data criteria } \\
\text { to predict eventual response } \\
\text { were developed. }\end{array}$ & $\begin{array}{l}\text { Combining functional and } \\
\text { anatomic imaging parameters } \\
\text { from }\left[^{18} \mathrm{~F} F \mathrm{FDG} \text { PET/CT scans }\right. \\
\text { performed early during } \\
\text { immunotherapy appears } \\
\text { predictive for eventual } \\
\text { response in patients with } \\
\text { advanced melanoma. }\end{array}$ \\
\hline Dercle et al. [49] & retrospective & $\begin{array}{l}16 \text { heavily pre-treated patients } \\
\text { with Hodgkin's Lymphoma (HL). }\end{array}$ & $\begin{array}{l}\text { To define the depth } \\
\text { and time of maximal } \\
\text { anti-tumor response } \\
\text { to anti-PD1 in heavily } \\
\text { pre-treated patients } \\
\text { with HL. }\end{array}$ & $\begin{array}{l}\text { The }\left[^{18} \mathrm{~F}\right] \mathrm{FDG} \text { PET/CT and CT } \\
\text { data of all relapsed or } \\
\text { refractory HL were reviewed } \\
\text { according to the International } \\
\text { Harmonisation Project Cheson } \\
2014 \text { criteria and the LYRIC } \\
\text { criteria. }\end{array}$ & $\begin{array}{l}\text { Fifty-six percent of patients } \\
\text { (9/16) achieved an objective } \\
\text { response at } 3 \text { months, } \\
\text { including } 19 \%(3 / 16) \text { of } \\
\text { complete response. Seventeen } \\
\text { percent }(1 / 6) \text { of partial } \\
\text { responders at } 3 \text { months were } \\
\text { converted in a complete } \\
\text { response. } 22 \%(2 / 9) \text { of } \\
\text { responders at } 3 \text { months } \\
\text { relapsed before one year. The } \\
\text { nadir was reached at } 12.7 \\
\text { (3.0-23.0) months. The median } \\
\text { (range) depth of response at } \\
\text { nadir was }-77 \%(-50 \% \text { to } 100 \%) \text {. }\end{array}$ & $\begin{array}{c}\text { Complete metabolic responses } \\
\text { occurred within } 6 \text { months, a } \\
\text { minority of partial responses } \\
\text { were converted in complete } \\
\text { response, and the median nadir } \\
\text { was observed one year after } \\
\text { treatment initiation. These data } \\
\text { could help to better define the } \\
\text { optimal treatment strategy by } \\
\text { PET or CECT-directed } \\
\text { approaches }\end{array}$ \\
\hline
\end{tabular}


Table 2. Cont.

\begin{tabular}{|c|c|c|c|c|c|c|}
\hline Reference & Study Type & Patients' Characteristics & Aims & Methods & Results & Conclusions \\
\hline Tan et al. [57] & retrospective & $\begin{array}{l}140 \text { metastatic melanoma patients } \\
\text { treated with anti-PD-1-based } \\
\text { immunotherapy with baseline and } \\
\left.\text { 1-year }{ }^{18} \mathrm{~F}\right] \mathrm{FDG} \text { PET and } \mathrm{CT} \\
\text { imaging. }\end{array}$ & $\begin{array}{c}\text { To investigate } \\
\text { whether }{ }^{18} \mathrm{~F} F \mathrm{FDG} \\
\text { PET may better } \\
\text { predict long-term } \\
\text { outcomes compared } \\
\text { with } \mathrm{CT}\end{array}$ & $\begin{array}{c}\text { One-year response was } \\
\text { determined using RECIST for } \\
\text { CT and EORTC criteria for PET. } \\
\text { PFS was determined from the } \\
\text { 1-year landmark. }\end{array}$ & $\begin{array}{l}\text { Whilst only a small proportion } \\
\text { of patients have a CR at } 1 \text { year, } \\
\text { most patients with a PR have } \\
\text { CMR on PET. Almost all } \\
\text { patients with CMR at } 1 \text { year } \\
\text { have ongoing response to } \\
\text { therapy thereafter. }\end{array}$ & $\begin{array}{l}\text { PET may have utility in } \\
\text { predicting long-term benefit } \\
\text { and help guide discontinuation } \\
\text { of therapy. }\end{array}$ \\
\hline Ito et al. [50] & retrospective & $\begin{array}{c}60 \text { patients with metastatic } \\
\text { melanoma who underwent } \\
{\left[^{18} \mathrm{~F}\right] \mathrm{FDG} \text { PET/CT scans both }} \\
\text { before and after ipilimumab } \\
\text { therapy. }\end{array}$ & $\begin{array}{l}\text { To evaluate the } \\
\text { association between } \\
\text { tumor response on } \\
{\left[{ }^{18} \mathrm{~F}\right] \mathrm{FDG} \text { PET/CT and }} \\
\text { prognosis in patients } \\
\text { with metastatic } \\
\text { malignant melanoma } \\
\text { treated with } \\
\text { ipilimumab. }\end{array}$ & $\begin{array}{l}\text { Tumor response was assessed } \\
\text { by the change in the sum of } \\
\text { SULpeak of up to } 5 \text { lesions } \\
\text { according to PERCIST5. New } \\
\text { lesions on PET that appeared } \\
\text { suggestive of metastases were } \\
\text { considered PMDD. } \\
\text { An immunotherapy-modified } \\
\text { response classification was also } \\
\text { evaluated (imPERCIST5). }\end{array}$ & $\begin{array}{c}\text { In responders and } \\
\text { non-responders, the } 2 \text {-y OS } \\
\text { was } 66 \% \text { versus } 29 \% \text { for } \\
\text { imPERCIST5 }(p=0.003) \text {. After } \\
\text { multivariate analysis, } \\
\text { imPERCIST5 remained } \\
\text { prognostic }(p=0.005) \text {. New } \\
\text { sites of focal [ }{ }^{18} \text { F]FDG uptake } \\
\text { occurred more often in patients } \\
\text { with PMD }(n=24) \text { by } \\
\text { imPERCIST5 than in those } \\
\text { with stable metabolic disease }(n \\
\text { = 7) or partial metabolic } \\
\text { response }(n=4) \text {. }\end{array}$ & $\begin{array}{l}\text { In patients with metastatic } \\
\text { melanoma treated with } \\
\text { ipilimumab, tumor response } \\
\text { according to PERCIST was } \\
\text { associated with OS. Our data } \\
\text { suggest that PMD should not } \\
\text { be defined by the appearance } \\
\text { of new lesions, but rather by an } \\
\text { increase in the sum of } \\
\text { SULpeak. }\end{array}$ \\
\hline Jreige et al. [58]] & retrospective & $\begin{array}{l}49 \text { patients with confirmed } \\
\text { NSCLC. }\end{array}$ & $\begin{array}{c}\text { To investigate } \\
\text { correlation between } \\
{\left[^{18} \mathrm{~F}\right] \mathrm{FDG}} \\
\text { PET/CT-based } \\
\text { markers and tumor } \\
\text { tissue expression of } \\
\text { PD-L1, necrosis and } \\
\text { clinical outcome in } \\
\text { patients treated with } \\
\text { ICPIs }\end{array}$ & $\begin{array}{l}\text { SUVmax, SUVmean, MTV and } \\
\text { TLG were obtained from } \\
{\left[^{18} \mathrm{~F}\right] \mathrm{FDG} \text { PET/CT images. }} \\
\text { Metabolic-to-morphological } \\
\text { volume ratio (MMVR) was } \\
\text { measured. }\end{array}$ & $\begin{array}{l}\text { All tumors showed metabolic } \\
{\left[{ }^{18} \text { t]FDG PET uptake. MMVR }\right.} \\
\text { was correlated inversely with } \\
\text { PD-L1 expression in tumor } \\
\text { cells. Furthermore, PD-L1 } \\
\text { expression and low MMVR } \\
\text { were significantly correlated } \\
\text { with clinical benefit. Necrosis } \\
\text { was correlated negatively with } \\
\text { MMVR. }\end{array}$ & $\begin{array}{l}\text { MMVR was introduced as a } \\
\text { new imaging biomarker and its } \\
\text { ability to noninvasively } \\
\text { capture increased PD-L1 tumor } \\
\text { expression and predict clinical } \\
\text { benefit from checkpoint } \\
\text { blockade in NSCLC should be } \\
\text { further evaluated. }\end{array}$ \\
\hline Amrane et al. [59] & retrospective & $\begin{array}{l}37 \text { patients with unresectable } \\
\text { metastatic cutaneous melanoma } \\
\text { eligible for immunotherapy. }\end{array}$ & $\begin{array}{c}\text { To assess serial } \\
\left.{ }^{18} \mathrm{~F}\right] \mathrm{FDG} \text { PET/CT } \\
\text { imaging according to } \\
\text { morphological and } \\
\text { functional to predict } \\
\text { clinical response to } \\
\text { therapy in patients } \\
\text { with advanced } \\
\text { melanoma receiving } \\
\text { immune checkpoint } \\
\text { blocking agents. }\end{array}$ & $\begin{array}{l}\text { Among } 37 \text { assessed patients, } 27 \\
\text { had } 1 \text { line of ICI, } 8 \text { had } 2 \text { lines } \\
\text { of ICI and } 2 \text { patients had } 3 \text { lines } \\
\text { of ICI: total of } 49 \text { PET/CTs. }\end{array}$ & $\begin{array}{c}\text { Median PFS was } 29.62 \text { months } \\
(p=0.001: \text { RECIST 1.1), }(p< \\
\text { 0.0001: iRECIST), }(p=0.000: \\
\text { PERCIST), }(p=0.072: \text { PECRIT). } \\
\text { Median OS was } 36.62 \text { months } \\
(p=0.005: \text { RECIST 1.1), }(p< \\
\text { 0.0001: } R \text { RECIST), }(p=0.001: \\
\text { PERCIST), }(p=0.082 \text { PECRIT). }\end{array}$ & $\begin{array}{l}{\left[{ }^{18} \mathrm{~F}\right] \mathrm{FDG} \text { PET/CT scans could }} \\
\text { detect eventual ICI-response in } \\
\text { patients with metastatic } \\
\text { melanoma. According to our } \\
\text { study, iRECIST and PERCIST } \\
1.0 \text { may provide the most } \\
\text { optimal ICI-related response } \\
\text { classification. }\end{array}$ \\
\hline
\end{tabular}


Table 2. Cont.

\begin{tabular}{|c|c|c|c|c|c|c|}
\hline Reference & Study Type & Patients' Characteristics & Aims & Methods & Results & Conclusions \\
\hline Rossi et al. [51] & prospective & 72 patients with advanced NSCLC. & $\begin{array}{l}\text { To compare the } \\
\text { evaluation of first } \\
\text { response to } \\
\text { Nivolumab by means } \\
\text { of CT-based criteria } \\
\text { with respect to } \\
{ }^{18} \mathrm{~F} \text { FDG PET } \\
\text { response criteria in } \\
\text { NSCLC patients. }\end{array}$ & $\begin{array}{l}\text { Patients underwent CT scan } \\
\text { and FDG-PET at baseline and } \\
\text { after } 4 \text { cycles (first evaluation). } \\
\text { Response was evaluated with } \\
\text { CT scan by means RECIST } 1.1 \\
\text { and IrRC and with FDG-PET } \\
\text { by means of PERCIST and } \\
\text { imPERCIST criteria. The } \\
\text { concordance between CT- and } \\
\text { PET-based criteria and the } \\
\text { capability of each method to } \\
\text { OS were evaluated. }\end{array}$ & $\begin{array}{l}\text { A low concordance between } \\
\text { CT- and PET-based criteria was } \\
\text { observed. Looking at OS, IrRC } \\
\text { were more reliable to } \\
\text { distinguish responders from } \\
\text { non-responders. However, } \\
\text { thanks to the prognostic value } \\
\text { of partial metabolic response } \\
\text { assessed by both PERCIST and } \\
\text { Immuno-PERCIST, PITE-based } \\
\text { response maintained } \\
\text { prognostic significant in } \\
\text { patients classified as } \\
\text { progressive disease on the } \\
\text { basis of IrRC. }\end{array}$ & $\begin{array}{l}\text { The added prognostic value of } \\
\text { the metabolic response } \\
\text { assessment, potentially } \\
\text { improving the therapeutic } \\
\text { decision-making was } \\
\text { suggested. }\end{array}$ \\
\hline Castello et al. [60] & prospective & $\begin{array}{l}50 \text { NSCLC patients treated with } \\
\text { ICIs. }\end{array}$ & $\begin{array}{c}\text { To investigate the } \\
\text { prevalence of such a } \\
\text { phenomenon and to } \\
\text { assess its association } \\
\text { with clinical variables } \\
\text { and metabolic } \\
\text { parameters by } \\
{\left[{ }^{18} \mathrm{~F}\right] \mathrm{FDG} \mathrm{PET} / \mathrm{CT} \text {. }}\end{array}$ & $\begin{array}{l}\text { All patients underwent } \\
\text { contrast-enhanced CT, } \\
{\left[{ }^{18} \mathrm{~F}\right] \mathrm{FDG} \text { PET/CT, }} \\
\text { and complete peripheral blood } \\
\text { sampling at baseline before ICI } \\
\text { treatment. A Cox proportional } \\
\text { hazards regression analysis } \\
\text { was used to evaluate factors } \\
\text { independently associated with } \\
\text { OS. }\end{array}$ & $\begin{array}{l}\text { Survival analysis showed a } \\
\text { median OS of } 4 \text { months for the } \\
\text { HPD group, compared with } 15 \\
\text { mo for the non-HPD group }(p \\
=0.003) \text {. Median OS was } \\
\text { significantly different when all } \\
\text { the response categories were } \\
\text { considered. Multivariate } \\
\text { analysis identififed MTV and } \\
\text { derived } \\
\text { neutrophil-to-lymphocyte ratio } \\
\text { as independent predictors for } \\
\text { OS. }\end{array}$ & $\begin{array}{l}\text { The use of ICIs might represent } \\
\text { a concern in patients with high } \\
\text { metabolic tumor burden and } \\
\text { inflammatory indices at } \\
\text { baseline. }\end{array}$ \\
\hline Annovazzi et al. [61] & retrospective & $\begin{array}{l}57 \text { patients with metastatic } \\
\text { melanoma treated with } \\
\text { ipilimumab or with PD-1 } \\
\text { inhhibitors who performed an } \\
\left.\text { [18 }^{18} \mathrm{~F}\right] \mathrm{FDG} \text { PET/CT scan before } \\
\text { treatment and } 12 \text { to } 18 \text { weeks later. }\end{array}$ & $\begin{array}{l}\text { To compare the } \\
\text { diagnostic accuracy of } \\
\text { different } \mathrm{I}^{18} \mathrm{~F} F \mathrm{FDG} \\
\mathrm{PET} / \mathrm{CT} \text { criteria to } \\
\text { predict therapy } \\
\text { response and clinical } \\
\text { outcome in } \\
\text { melanoma patients } \\
\text { treated with immune } \\
\text { checkpoint inhibitors. }\end{array}$ & $\begin{array}{l}\text { Response at PET1 was } \\
\text { evaluated according to RECIST } \\
\text { 1.1, EORTC, PERCIMT, and by } \\
\text { percentage change of (MTV) } \\
\text { and TLG of up to } 5 \text { target } \\
\text { lesions. Performance of each } \\
\text { criterion at PET1 to predict } \\
\text { clinical benefit at } 6 \text { months } \\
\text { since starting immunotherapy } \\
\text { was assessed and correlated to } \\
\text { PFS. }\end{array}$ & $\begin{array}{l}\text { The best predictor of therapy } \\
\text { response was MTV combined } \\
\text { with PERCIMT criteria } \\
\text { (accuracy, } 0.96 \text { ). In group 2, } \\
\text { overlapping results were found } \\
\text { for EORTC, MTV, and total } \\
\text { lesion glycolysis (accuracy, } \\
\text { 0.97). The reliability of the } \\
\text { above parameters was also } \\
\text { confirmed in the } \\
\text { progression-free survival } \\
\text { analysis. }\end{array}$ & 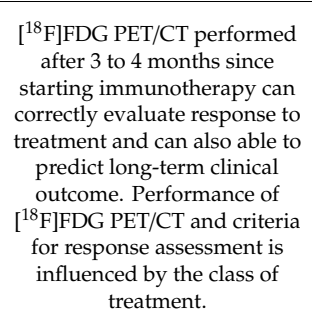 \\
\hline
\end{tabular}


Table 2. Cont.

\begin{tabular}{|c|c|c|c|c|c|c|}
\hline Reference & Study Type & Patients' Characteristics & Aims & Methods & Results & Conclusions \\
\hline Castello et al. [62] & prospective & 35 NSCLC patients & $\begin{array}{l}\text { To examine CTC } \\
\text { count and its } \\
\text { association with } \\
\text { metabolic parameters } \\
\text { and clinical outcomes } \\
\text { in NSCLC patients } \\
\text { treated with ICI. }\end{array}$ & $\begin{array}{l}\text { All patients underwent an } \\
\text { [18F/FDG PET/CT scan and } \\
\text { CTC detection through } \\
\text { Isolation by Size of } \\
\text { Tumor/Trophoblastic Cells } \\
\text { (ISET) from peripheral blood } \\
\text { samples obtained at baseline } \\
\text { and } 8 \text { weeks after ICI initiation. } \\
\text { Association of CTC count with } \\
\text { clinical and metabolic } \\
\text { characteristics was studied. }\end{array}$ & $\begin{array}{l}\Delta C T C \text { was significantly } \\
\text { associated with tumor } \\
\text { metabolic response set by } \\
\text { ORTC criteria }(p=0.033) \text {. At } \\
\text { the first restaging, patients } \\
\text { with a high tumor burden, that } \\
\text { is, metabolic tumor volume } \\
\text { (MTV) and total lesion } \\
\text { glycolysis (TLG), had a higher } \\
\text { CTC count }(p=0.009) \text {. } \\
\text { Multivariate analysis identified } \\
\text { CTC count at } 8 \text { weeks as an } \\
\text { independent predictor for PFS } \\
\text { and OS, whereas } \triangle \text { MTV and } \\
\text { maximum standardized uptake } \\
\text { value variation ( } \Delta \text { USVmax) } \\
\text { was predictive for PFS and OS, } \\
\text { respectively. }\end{array}$ & $\begin{array}{l}\text { CTC number is modulated by } \\
\text { previous treatments and } \\
\text { correlates with metabolic } \\
\text { response during ICI. Moreover, } \\
\text { elevated CTC count, along } \\
\text { with metabolic parameters, are } \\
\text { prognostic factors for PFS and } \\
\text { OS. }\end{array}$ \\
\hline Hashimoto et al. [63] & retrospective & $\begin{array}{l}85 \text { patients with previously treated } \\
\text { NSCLC who underwent }\left[^{18} \mathrm{~F}\right] \mathrm{FDG} \\
\text { PET just before administration of } \\
\text { nivolumab or pembrolizumab. }\end{array}$ & $\begin{array}{l}\text { To retrospectively } \\
\text { examine the } \\
\text { prognostic } \\
\text { significance of } \\
{\left[{ }^{18} \text { F]FDG uptake as a }\right.} \\
\text { predictive marker of } \\
\text { anti-PD-1 antibody. }\end{array}$ & $\begin{array}{l}\text { MTV, TLG and SUVmax on } \\
{\left[{ }^{18} \text { F]FDG uptake were }\right.} \\
\text { assessed. }\end{array}$ & $\begin{array}{l}\text { The tumor metabolic activity } \\
\text { by TLG and MTV was } \\
\text { identified as an independent } \\
\text { prognostic factor for predicting } \\
\text { outcome after anti-PD-1 } \\
\text { antibody therapy. }\end{array}$ & $\begin{array}{l}\text { TLG and MTV on }\left[{ }^{18} \mathrm{~F}\right] \text { FDG } \\
\text { uptake may predict the } \\
\text { prognosis after anti-PD-1 } \\
\text { antibodies in patients with } \\
\text { previously treated NSCLC. }\end{array}$ \\
\hline Seban et al. [64] & retrospective & $\begin{array}{l}56 \text { patients with non-resectable } \\
\text { mucosal melanoma (Muc-M) or } \\
\text { cutaneous melanoma (Cut-M) who } \\
\text { underwent baseline }{ }^{18} \mathrm{~F} \text { FDEG } \\
\text { PET/CT before treatment with ICIs. }\end{array}$ & $\begin{array}{c}\text { To compare the } \\
\text { prognostic value of } \\
\text { imaging biomarkers } \\
\text { derived from a } \\
\text { quantitative analysis } \\
\text { of baseline }\left[{ }^{18} \mathrm{~F}\right] \mathrm{FDG} \\
\text { PET/CT in patients } \\
\text { with mucosal } \\
\text { melanoma (Muc-M) } \\
\text { or cutaneous } \\
\text { melanoma (Cut-M) } \\
\text { treated with ICIs. }\end{array}$ & $\begin{array}{l}\text { Parameters were extracted } \\
\text { from (i) tumoral tissues: } \\
\text { SUVmax, SUVmean, TMTV } \\
\text { and TLG and (ii) lymphoid } \\
\text { tissues: BLR and SLR. } \\
\text { Association with survival and } \\
\text { response was evaluated using } \\
\text { Cox prediction models, }\end{array}$ & $\begin{array}{l}\text { In Muc-M, increased tumor } \\
\text { SUVmax was associated with } \\
\text { shorter OS while it was not } \\
\text { correlated with PFS, ORR, or } \\
\text { DCR. In Cut-M, increased } \\
\text { TMTV and increased BLR were } \\
\text { independently associated with } \\
\text { shorter OS, shorter PFS, } \\
\text { and lower response (ORR, } \\
\text { DCR). }\end{array}$ & $\begin{array}{l}\text { For Muc-M patients treated } \\
\text { with ICI, the only prognostic } \\
\text { imaging biomarker was a high } \\
\text { baseline maximal glycolytic } \\
\text { activity (SUVmax), whereas for } \\
\text { Cut-M patients, baseline } \\
\text { metabolic tumor burden or } \\
\text { bone marrow metabolism was } \\
\text { negatively correlated to ICI } \\
\text { response duration. }\end{array}$ \\
\hline Nakamoto et al. [65] & retrospective & $\begin{array}{l}85 \text { melanoma patients treated with } \\
\text { ICIs who underwent PET/CT scans } \\
\text { before and approximately } 3 \\
\text { months after the start of } \\
\text { immunotherapy. }\end{array}$ & $\begin{array}{l}\text { To investigate the } \\
\text { prognostic value of } \\
\text { MTV and other } \\
\text { metabolic tumor } \\
\text { parameters, obtained } \\
\text { from baseline and first } \\
\text { restaging }\left[{ }^{18} \mathrm{~F}\right] \mathrm{FDG} \\
\text { PET/CT scans in } \\
\text { melanoma patients } \\
\text { treated with ICIs. }\end{array}$ & $\begin{array}{l}\text { Metabolic tumor parameters } \\
\text { including MTV for all } \\
\text { melanoma lesions were } \\
\text { measured on each scan. A Cox } \\
\text { proportional hazards model } \\
\text { was used for univariate and } \\
\text { multivariate analyses of } \\
\text { metabolic parameters } \\
\text { combined with known clinical } \\
\text { prognostic factors associated } \\
\text { OS. }\end{array}$ & $\begin{array}{l}\text { MTV obtained from first } \\
\text { restaging PET/CT scans } \\
\text { (MTVpost) was the strongest } \\
\text { prognostic factor for OS among } \\
\text { PET/CT parameters ( }(p< \\
\text { 0.0001). The median OS in } \\
\text { patients with high MTVpost ( } \geq \\
\text { 23.44) was } 16 \text { months as } \\
\text { compared with more than } 60 \\
\text { months in patients with low } \\
\text { MTVpost }(p=0.0003) \text {. }\end{array}$ & $\begin{array}{l}\text { Whole-body metabolic tumor } \\
\text { volume from PET scan } \\
\text { acquired approximately } 3 \\
\text { months following initiation of } \\
\text { immunotherapy (MTVpost) is } \\
\text { a strong prognostic indicator of } \\
\text { OS in melanoma patients. }\end{array}$ \\
\hline
\end{tabular}


Table 2. Cont

\begin{tabular}{|c|c|c|c|c|c|c|}
\hline Reference & Study Type & Patients' Characteristics & Aims & Methods & Results & Conclusions \\
\hline Iravani et al. [66] & retrospective & $\begin{array}{l}31 \text { patients who had first-line } \\
\text { nivolumab plus ipilimumab; pre- } \\
\text { and post-treatment }\left[\left[^{18} \mathrm{~F}\right] \mathrm{FDG}\right. \\
\text { PET/CT scans within } 2 \text { and } 4 \\
\text { months of starting ICI, respectively } \\
\text { and at least one lesion assessable } \\
\text { by PERCIST. }\end{array}$ & $\begin{array}{l}\text { To investigate the role } \\
\text { of }{ }^{18} \mathrm{~F} \text { FDG PET/CT } \\
\text { in monitoring of } \\
\text { response and } \\
\text { immune-related } \\
\text { adverse events } \\
\text { following first-line } \\
\text { combination-ICI } \\
\text { therapy for advanced } \\
\text { melanoma. }\end{array}$ & $\begin{array}{l}\text { Outcomes in patients who had } \\
\text { first-line nivolumab plus } \\
\text { ipilimumab were reviewed; } \\
\text { pre- and post-treatment } \\
\text { FDG-PET/CT scans within } 2 \\
\text { and } 4 \text { months of starting ICI, } \\
\text { respectively; and at least one } \\
\text { lesion assessable by PERCIST. }\end{array}$ & 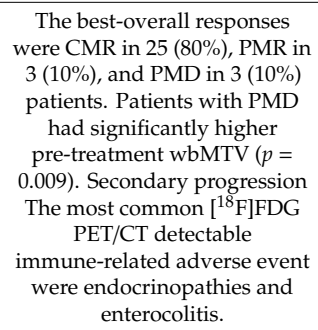 & $\begin{array}{l}{\left[{ }^{18} \mathrm{FJFDG} \text { PET/CT response }\right.} \\
\text { evaluation predicts the } \\
\text { lon-term outcome of patients } \\
\text { treated with first-line } \\
\text { combination-ICIs.. Beyond } \\
\left.\text { response assessment, }{ }^{18 \mathrm{~F}} \mathrm{~F}\right] \mathrm{FDDG} \\
\text { PET/CT frequently detects } \\
\text { clinically relevant irAEs. }\end{array}$ \\
\hline Umeda et al. [67] & prospective & 25 with previously treated NSCLC & $\begin{array}{c}\text { To determine whether } \\
\text { changes in integrated } \\
\left.\text { [ }^{18} \mathrm{~F}\right] \mathrm{FDG} \text { PET/MRI } \\
\text { parameters after the } \\
\text { first } 2 \text { weeks of } \\
\text { antiprogrammed } \\
\text { death-1 antibody } \\
\text { nivolumab therapy } \\
\text { could predict the } \\
\text { response of patients } \\
\text { with NSCLC. }\end{array}$ & $\begin{array}{l}\text { Patients underwent }\left[{ }^{18} \mathrm{~F}\right] \mathrm{FDG} \\
\text { PET/MRI before and at } 2 \text { weeks } \\
\text { after nivolumab therapy. } \\
\text { Changes in SUVmax, } \Delta \mathrm{TLG} \\
\text { and } \triangle \mathrm{ADC} \text { between the two } \\
\text { scans were calculated and } \\
\text { evaluated for their associations } \\
\text { with the clinical response to } \\
\text { therapy. }\end{array}$ & $\begin{array}{c}\text { Non-PD patients had } \\
\text { significantly decreased TLG, } \\
\text { increased ADCmean and lower } \\
\Delta \mathrm{TLG}+\Delta \mathrm{ADCmean} \text { than PD } \\
\text { patients. }\end{array}$ & $\begin{array}{l}\text { A combination of } \triangle T L G \text { and } \\
\triangle A D C m \text { man measured by } \\
\text { integrated }\left[^{18} \mathrm{~F}\right] \mathrm{FDG} \text { PET/MRI } \\
\text { may have value as a predictor } \\
\text { of the response and survival of } \\
\text { patients with NSCLC following } \\
\text { nivolumab therapy. }\end{array}$ \\
\hline Castello et al. [68] & prospective & $\begin{array}{l}20 \text { NSCLC patients candidate to } \\
\text { ICI therapy. }\end{array}$ & $\begin{array}{l}\text { To investigate the role } \\
\text { of sPD-L1 in NSCLC } \\
\text { patients treated with } \\
\text { ICI and to analyze its } \\
\text { association with } \\
\text { clinical outcomes and } \\
\text { metabolic parameters } \\
\left.\text { by }{ }^{18}{ }^{18} \mathrm{~F}\right] \mathrm{FDG} \text { PE T/CT. }\end{array}$ & $\begin{array}{l}\text { Patients who had serum frozen } \\
\left.\text { samples and }{ }^{18} \mathrm{~F}\right] \mathrm{FDG} \text { PET/CT } \\
\text { available, both at baseline and } \\
\text { at the first restaging after } \\
\text { approximately three or four } \\
\text { cycles of ICI, were included. } \\
\text { Before and after } 3-4 \text { cycles of } \\
\text { ICI, peripheral blood samples } \\
\text { were collected from patients. }\end{array}$ & $\begin{array}{l}\text { A significant association } \\
\text { between patients with elevated } \\
\text { SPD-L1, above the median } \\
\text { value, and high metabolic } \\
\text { tumor burden, expressed by } \\
\text { MTV ( } p=0.034) \text { and TLG ( } p= \\
\text { 0.049) was found. At the first } \\
\text { restaging after 7-8 weeks, } \\
\text { median sPD-L1 levels } \\
\text { significantly increased as } \\
\text { compared to baseline median } \\
\text { value }(p=0.017) \text {. }\end{array}$ & $\begin{array}{l}\text { The association between } \\
\text { metabolic tumor burden and } \\
\text { sPD-L1 levels, as well as a } \\
\text { significant increase of fPD-L1 } \\
\text { during treatment with ICI were } \\
\text { demonstrated. PD-L1 can be } \\
\text { used as a new biomarker in the } \\
\text { early assessment and } \\
\text { monitoring of immunotherapy } \\
\text { efficacy. }\end{array}$ \\
\hline
\end{tabular}

CT: computed tomography; PD: progressive disease; CR: complete response; NSCLC: non-small-cell lung cancer; ICPIs: immune checkpoint inhibitors; iMPERCIST: immunotherapy-modified PERCIST; IrRC: immune-related response; OS: Overall Survival; PFS: progression free survival; iRECIST: immune-related Response Evaluation Criteria in Solid Tumors. 


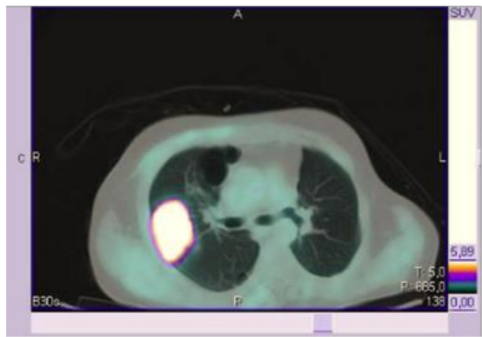

(b)

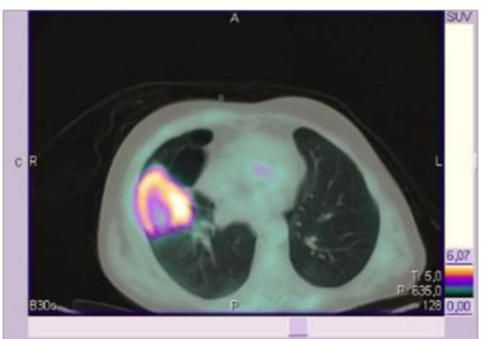

(c)

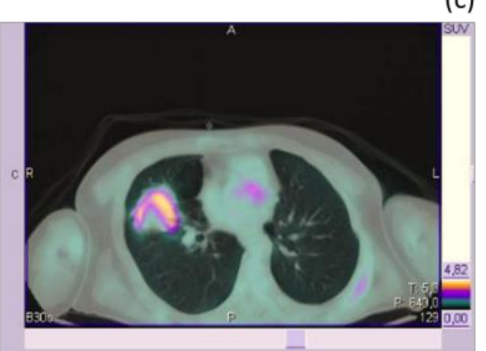

Figure 2. A representative example of metabolic response in patients with advanced NSCLC treated with Nivolumab. Baseline $\left[{ }^{18} \mathrm{~F}\right] \mathrm{FDG}$ PET/CT (a) shows a right parascissural lung lesion (dd max $7 \mathrm{~cm}$; SUVmax 12). Only a mild reduction in lesion size was highlighted at the first response evaluation (2 months after therapy; b); however, a more marked metabolic reduction was already evident (SUVmax 6). Of note, a metabolic active volume reduction was even more evident than a SUVmax reduction as a central photopenic area was evident after treatment. The first metabolic response was able to predict the patient's response evolution, as after a further two months, both lesion size and metabolism were further decreased (SUVmax 4, c). NSCLC: Non Small Cell Lung Cancer.

\section{Response Assessment and Prediction with NON-FDG Tracers}

\section{1. [11. C]choline, $\left[{ }^{18}\right.$ F]choline, and $\left[{ }^{68}\right.$ Ga]PSMA}

As mentioned, although not yet validated, several ongoing efforts are trying to explore (and possibly standardize) the use of objective criteria to report $\left[{ }^{18} \mathrm{~F}\right] \mathrm{FDG}$ PET/CT in patients treated with target therapies. By contrast, very few studies addressed the capability of standardized PET response evaluation to target (and either conventional) therapies carried out with non-FDG PET tracers. A preliminary experience is available for $\left[{ }^{11} \mathrm{C}\right]$ choline PET/CT. De Giorgi et al. $[69,70]$ assessed the usefulness of $\left[{ }^{18} \mathrm{~F}\right]$ choline PET/CT for evaluating early response to abiraterone and enzalutamide in mCRPC patients. A radiologic response was associated with more favorable overall survival than a PSA response of greater than or equal to $50 \%$ alone. Maines et al. [71] evaluated $\left[{ }^{18} \mathrm{~F}\right]$ choline $\mathrm{PET} / \mathrm{CT}$ in monitoring response to enzalutamide in $30 \mathrm{mCRPC}$ patients. SUVmax measured at baseline before enzalutamide was significantly related to radiologic progression-free survival and overall survival. Middendorp et al. [72] reported that response evaluation based on $\left[{ }^{18} \mathrm{~F}\right]$ choline PET/CT results after tyrosine kinase inhibitor treatment was effective to predict outcome in two renal cell carcinoma patients. Similarly, Kitajima et al. [73] performed 34 scans before/after a combined total of 17 courses of treatment, including molecular target therapy and immunotherapy, in 6 patients with prostate cancer and 2 with renal cell carcinoma. $\left[{ }^{11} \mathrm{C}\right]$ choline PET/CT was useful for detecting viable residual tumors and evaluating the treatment response, showing a better treatment response than CT. In more recent years, PSMA, a transmembrane glycoprotein highly expressed on the cell surface of prostate cancer cells, with expression increasing with more aggressive cancer types and in castration-resistant disease, has emerged as a compound of utmost importance for imaging and therapy of prostate cancer [74]. In the last years, PET with $\left[{ }^{68} \mathrm{Ga}\right]$ PSMA has become increasingly proposed especially for the early and accurate detection of disease relapse [74]. Its role in post-treatment settings is less defined; however, the possibility of labelling PSMA with the beta-emitter ${ }^{177} \mathrm{Lu}$ has opened a further therapeutic opportunity in prostate cancer patients whose effect can be evaluated by means of $\left[{ }^{68} \mathrm{Ga}\right]$ PSMA PET [75-77]. Indeed, PSMA PET has a role in predicting treatment response to $\left[{ }^{177} \mathrm{Lu}\right]$ PSMA therapy and in identifying subsequent patterns of failure, determining the next best treatment options [75-77]. A minimal PSMA receptor density threshold is required to get any treatment response while factors that determine treatment response to $\left[{ }^{177} \mathrm{Lu}\right] \mathrm{PSMA}$ therapy are homogeneity of PSMA receptor expression across cancer cells, radiation sensitivity, and a hypoxic status of these cells [78]. Identifying patterns of response or failure on PSMA imaging after $\left[{ }^{177} \mathrm{Lu}\right] \mathrm{PSMA}$ therapy 
may, in the near future, to determine subsequent treatment options after or in addition to [ $\left.{ }^{177} \mathrm{Lu}\right] \mathrm{PSMA}$ therapy [79].

\section{2. [68. Ga]DOTA-Conjugate Peptides}

Even before the availability of target and radiometabolic options for patients with advanced prostate cancer, another pathway has been significantly investigated and used in the field of nuclear medicine both for diagnostic and treatment purposes. The somatostatin receptor (SSTR), expressed by most neuroendocrine neoplasms (NENs), can in fact be the targets for radionuclide imaging and therapy. $\left[{ }^{68} \mathrm{Ga}\right.$ ]DOTA-conjugate peptides (DOTA-TATE, DOTA-TOC, and DOTA-NOC) PET/CT are used to determine SSTR status (patients with SSTR-positive tumors are more likely to respond to targeted somatostatin analogue therapy), to predict therapeutic response to peptide receptor radionuclide therapy (PRRT) and to monitor the response to PRRT [80]. PRRT is successfully used to target metastatic or inoperable neuroendocrine tumors expressing subtype 2, leading to a longer survival and improved quality of life [81,82]. Evaluation of the response to treatment includes consideration of the morphological and PET/SPECT functional status. Functional imaging is a valuable instrument to assess the course of the disease, being able to predict morphological response. Combined functional and morphological imaging may in many cases better reflect the true behavior of the tumor following PRRT. However, functional imaging is not yet accepted as a substitute for morphological imaging to assess treatment tumor response [81].

\subsection{Other Non-FDG Tracers}

Finally, the ductility of PET technology has allowed the development of radiolabeled compounds able to directly track targets of target therapies in specific clinical settings. $16 \alpha$ - $\left[{ }^{18} \mathrm{~F}\right]$ fluoro- $17 \beta$-estradiol $\left(\left[{ }^{18} \mathrm{~F}\right] \mathrm{FES}\right)$ and $16 \beta-\left[{ }^{18} \mathrm{~F}\right]$ fluoro-5 $\alpha$-dihydrotestosterone ([18 F]FDHT) PET/CT allow visualization, respectively, of estrogen (ER) and androgen receptor (AR) status in tumor lesions. [ $\left.{ }^{18} \mathrm{~F}\right] \mathrm{FES}$ and $\left[{ }^{18}\right.$ F]FDHT uptake correlates well with ER and AR expression levels in breast and prostatic cancer [83-85]. Multiple tumor sites throughout the body can be evaluated without patient discomfort, even sites that would be challenging to reach by needle biopsy and sites where tissue processing can affect the ER assay. Thus, intertumoral heterogeneity can be detected by [ ${ }^{18}$ F]FES-PET [86-88], being predictive of a benefit from endocrine therapy [89]. [ ${ }^{18}$ F]FES PET can be used to assess residual ER availability during treatment [90]. In patients with prostate cancer, $\left[{ }^{18} \mathrm{~F}\right]$ FDHT PET was used to determine the optimal dose of the AR blocker enzalutamide in a phase 1 trial [91]. FES also represents the standard in vivo probe for pharmacodynamic target occupancy studies used to determine appropriate dosing of currently used ER antagonists [90,92].

In recent years, new and extremely promising non-FDG PET tracers have also been evaluated in the field of immunotherapy, with the aim of predicting response to ICPIs even before treatment [93,94]. In fact, PD-L1 expression by immunohistochemistry has been correlated with response and survival following PD-(L)1 monoclonal antibody therapy in patients with NSCLC [92]. However, a lack of response has also been demonstrated in patients with PD-L1 expression and has been linked to heterogeneity of PD-L1 expression within tumors. PET studies in preclinical models have tested this hypothesis. Indeed Niemeijer et al. and Bensch et al. reported the first-in-human results of whole body PET imaging by means of ${ }^{18} \mathrm{~F}-\mathrm{BMS}-986192,{ }^{89} \mathrm{Zr}$-Nivolumab, and ${ }^{89} \mathrm{Zr}$ atezolizumab prior to treatment with ICPIs in patients with different tumor types and, highlighted with whole body PD-(L)1 PET-CT, a significant tumor tracer uptake heterogeneity both in different patients and in different tumor lesions in the same patient $[93,94]$.

\section{Conclusions}

In conclusion, new and emerging therapeutic strategies in clinical oncology with a prominent cytostatic rather than cytotoxic effect have suggested a possible inadequacy of established morphologic size-based criteria for the assessment of tumor response in a subset of patients. Functional and 
molecular parameters for imaging are under intense investigation. In this framework, $\left[{ }^{18} \mathrm{~F}\right] \mathrm{FDG}$ PET, a widely available tool for imaging in oncology, has showed promising features in capturing an unexpected pattern of response as well as for the identification of non-responders. The added value of $\left[{ }^{18}\right.$ F]FDG PET can thus be of interest not only to avoid unnecessary toxicity (in non-responders) but also to support a treatment flow-chart that is sustainable for the healthcare system. In this regard, there is an urgent need to further validate and practically implement specific criteria for an objective evaluation of the PET-based response to new therapies. As a more systematic approach, $\left[{ }^{18} \mathrm{~F}\right] \mathrm{FDG}$ PET might also pave the path for a structured use of non-FDG PET tracers, thus completing exploiting the potential of PET technology in the emerging field of personalized cancer medicine.

Author Contributions: Conceptualization, M.I.D. and S.M.; Methodology, All Authors; Writing—Original draft preparation, All authors; Writing-Review and editing, All Authors. All authors have read and agreed to the published version of the manuscript.

Funding: This research received no external funding.

Conflicts of Interest: The authors declare no conflict of interest.

\section{References}

1. Jackson, S.E.; Chester, J.D. Personalised cancer medicine. Int. J. Cancer 2015, 137, 262-266. [CrossRef] [PubMed]

2. Hartmann, J.T.; Haap, M.; Kopp, H.G.; Lipp, H.P. Tyrosine kinase inhibitors-A review on pharmacology, metabolism and side effects. Curr. Drug Metab. 2009, 10, 470-481. [CrossRef] [PubMed]

3. Kantarjian, H.; Rajkumar, S.V. Why are cancer drugs so expensive in the United States, and what are the solutions? Mayo Clin. Proc. 2015, 90, 500-504. [CrossRef] [PubMed]

4. Serkova, N.J.; Eckhardt, S.G. Metabolic Imaging to Assess Treatment Response to Cytotoxic and Cytostatic Agents. Front. Oncol. 2016, 6, 152. [CrossRef]

5. O'Day, S.J.; Hamid, O.; Urba, W.J. Targeting cytotoxic T-lymphocyte antigen-4 (CTLA-4): A novel strategy for the treatment of melanoma and other malignancies. Cancer 2007, 110, 2614-2627. [CrossRef]

6. Geukes Foppen, M.H.; Rozeman, E.A.; van Wilpe, S.; Postma, C.; Snaebjornsson, P.; van Thienen, J.V.; van Leerdam, M.E.; van den Heuvel, M.; Blank, C.U.; van Dieren, J.; et al. Immune checkpoint inhibition-related colitis: Symptoms, endoscopic features, histology and response to management. ESMO Open 2018, 3, e000278. [CrossRef]

7. Wolchok, J.D.; Hoos, A.; O’Day, S.; Weber, J.S.; Hamid, O.; Lebbé, C.; Maio, M.; Binder, M.; Bohnsack, O.; Nichol, G.; et al. Guidelines for the evaluation of immune therapy activity in solid tumors: Immune-related response criteria. Clin. Cancer Res. 2009, 15, 7412-7420. [CrossRef]

8. Miller, A.B.; Hoogstraten, B.; Staquet, M.; Winkler, A. Reporting results of cancer treatment. Cancer 1981, 47, 207-214. [CrossRef]

9. Therasse, P.; Arbuck, S.G.; Eisenhauer, E.A.; Wanders, J.; Kaplan, R.S.; Rubinstein, L.; Verweij, J.; Van Glabbeke, M.; van Oosterom, A.T.; Christian, M.C.; et al. New guidelines to evaluate the response to treatment in solid tumors. J. Natl. Cancer. Inst. 2000, 92, 205-216. [CrossRef]

10. Eisenhauer, E.A.; Therasse, P.; Bogaerts, J.; Schwartz, L.H.; Sargent, D.; Ford, R.; Dancey, J.; Arbuck, S.; Gwyther, S.; Mooney, M.; et al. New response evaluation criteria in solid tumours: Revised RECIST guideline (version 1.1). Eur. J. Cancer 2009, 45, 228-247. [CrossRef]

11. Aykan, N.F.; Özatlı, T. Objective response rate assessment in oncology: Current situation and future expectations. World J. Clin. Oncol. 2020, 11, 53-73. [CrossRef] [PubMed]

12. Wahl, R.L.; Jacene, H.; Kasamon, Y.; Lodge, M.A. From RECIST to PERCIST: Evolving Considerations for PET response criteria in solid tumors. J. Nucl. Med. 2009, 50, 122S-150S. [CrossRef] [PubMed]

13. Young, H.; Baum, R.; Cremerius, U.; Herholz, K.; Hoekstra, O.; Lammertsma, A.A.; Pruim, J.; Price, P. Measurement of clinical and subclinical tumour response using $\left[{ }^{18} \mathrm{~F}\right]$-fluorodeoxyglucose and positron emission tomography: Review and 1999 EORTC recommendations. European Organization for Research and Treatment of Cancer (EORTC) PET Study Group. Eur. J. Cancer 1999, 35, 1773-1782. [CrossRef]

14. Min, S.J.; Jang, H.J.; Kim, J.H. Comparison of the RECIST and PERCIST criteria in solid tumors: A pooled analysis and review. Oncotarget 2016, 7, 27848-27854. [CrossRef] [PubMed] 
15. Odawara, S.; Kitajima, K.; Katsuura, T.; Kurahashi, Y.; Shinohara, H.; Yamakado, K. Tumor response to neoadjuvant chemotherapy in patients with esophageal cancer assessed with CT and FDG-PET/CT-RECIST 1.1 vs. PERCIST 1.0. Eur. J. Radiol. 2018, 101, 65-71. [CrossRef] [PubMed]

16. Belmouhand, M.; Löfgren, J.; Johannesen, H.H.; Baeksgaard, L.; Gutte, H.; Tariq, K.; Achiam, M.P. Early response evaluation of neoadjuvant therapy with PET/MRI to predict resectability in patients with adenocarcinoma of the esophagogastric junction. Abdom. Radiol. 2019, 44, 836-844. [CrossRef]

17. Grootjans, W.; de Geus-Oei, L.F.; Troost, E.G.; Visser, E.P.; Oyen, W.J.; Bussink, J. PET in the management of locally advanced and metastatic NSCLC. Nat. Rev. Clin. Oncol. 2015, 12, 395-407. [CrossRef]

18. Weber, W.A.; Petersen, V.; Schmidt, B.; Tyndale-Hines, L.; Link, T.; Peschel, C.; Schwaiger, M. Positron emission tomography in non-small-cell lung cancer: Prediction of response to chemotherapy by quantitative assessment of glucose use. J. Clin. Oncol. 2003, 21, 2651-2657. [CrossRef]

19. Ding, Q.; Cheng, X.; Yang, L.; Zhang, Q.; Chen, J.; Li, T.; Shi, H. PET/CT evaluation of response to chemotherapy in non-small cell lung cancer: PET response criteria in solid tumors (PERCIST) versus response evaluation criteria in solid tumors (RECIST). J. Thorac. Dis. 2014, 6, 677-683.

20. Pinker, K.; Riedl, C.; Weber, W.A. Evaluating tumor response with FDG PET: Updates on PERCIST, comparison with EORTC criteria and clues to future developments. Eur. J. Nucl. Med. Mol. Imaging 2017, 44, 55-66. [CrossRef]

21. Kruse, V.; Mees, G.; Maes, A.; D’Asseler, Y.; Borms, M.; Cocquyt, V.; Van De Wiele, C. Reproducibility of FDG PET based metabolic tumor volume measurements and of their FDG distribution within. Q. J. Nucl. Med. Mol. Imaging 2015, 59, 462-468. [PubMed]

22. Shady, W.; Kishore, S.; Gavane, S.; Do, R.K.; Osborne, J.R.; Ulaner, G.A.; Gonen, M.; Ziv, E.; Boas, F.E.; Sofocleous, C.T. Metabolic tumor volume and total lesion glycolysis on FDG-PET/CT can predict overall survival after (90)Y radioembolization of colorectal liver metastases: A comparison with SUVmax, SUVpeak, and RECIST 1.0. Eur. J. Radiol. 2016, 85, 1224-1231. [CrossRef]

23. Dosani, M.; Yang, R.; McLay, M.; Wilson, D.; Liu, M.; Yong-Hing, C.J.; Hamm, J.; Lund, C.R.; Olson, R.; Schellenberg, D. Metabolic tumour volume is prognostic in patients with non-small-cell lung cancer treated with stereotactic ablative radiotherapy. Curr. Oncol. 2019, 26, e57-e63. [CrossRef] [PubMed]

24. Suzuki, H.; Nishio, M.; Nakanishi, H.; Hanai, N.; Hirakawa, H.; Kodaira, T.; Tamaki, T.; Hasegawa, Y. Impact of total lesion glycolysis measured by ${ }^{18} \mathrm{~F}$-FDG-PET/CT on overall survival and distant metastasis in hypopharyngeal cancer. Oncol. Lett. 2016, 12, 1493-1500. [CrossRef]

25. Skusa, C.; Weber, M.A.; Böttcher, S.; Thierfelder, K.M. Criteria-Based Imaging and Response Evaluation of Lymphoma 20 Years after Cheson: What is New?-A Review of the Current Classifications. Rofo 2020, 192, 657-668. [CrossRef] [PubMed]

26. Barrington, S.F.; Mikhaeel, N.G.; Kostakoglu, L.; Meignan, M.; Hutchings, M.; Müeller, S.P.; Schwartz, L.H.; Zucca, E.; Fisher, R.I.; Trotman, J.; et al. Role of imaging in the staging and response assessment of lymphoma: Consensus of the International Conference on Malignant Lymphomas Imaging Working Group. J. Clin. Oncol. 2014, 32, 3048-3058. [CrossRef]

27. Hutchings, M.; Loft, A.; Hansen, M.; Pedersen, L.M.; Buhl, T.; Jurlander, J.; Buus, S.; Keiding, S.; D'Amore, F.; Boesen, A.M.; et al. FDG-PET after two cycles of chemotherapy predicts treatment failure and progression-free survival in Hodgkin lymphoma. Blood 2006, 107, 52-59. [CrossRef]

28. Gallamini, A.; Hutchings, M.; Rigacci, L.; Specht, L.; Merli, F.; Hansen, M.; Patti, C.; Loft, A.; Di Raimondo, F.; D'Amore, F. Early interim 2-[ $\left.{ }^{18} \mathrm{~F}\right]$ fluoro-2-deoxy-D-glucose positron emission tomography is prognostically superior to international prognostic score in advanced-stage Hodgkin's lymphoma: A report from a joint Italian-Danish study. J. Clin. Oncol. 2007, 25, 3746-3752. [CrossRef]

29. Von Mehren, M.; Joensuu, H. Gastrointestinal Stromal Tumors. J. Clin. Oncol. 2018, 36, 136-143. [CrossRef]

30. Stroobants, S.; Goeminne, J.; Seegers, M.; Dimitrijevic, S.; Dupont, P.; Nuyts, J.; Martens, M.; van den Borne, B.; Cole, P.; Sciot, R.; et al. ${ }^{18}$ FDG-Positron emission tomography for the early prediction of response in advanced soft tissue sarcoma treated with imatinib mesylate (Glivec). Eur. J. Cancer 2003, 39, $2012-2020$. [CrossRef]

31. Sunaga, N.; Oriuchi, N.; Kaira, K.; Yanagitani, N.; Tomizawa, Y.; Hisada, T.; Ishizuka, T.; Endo, K.; Mori, M. Usefulness of FDG-PET for early prediction of the response to gefitinib in non-small cell lung cancer. Lung Cancer 2008, 59, 203-210. [CrossRef] [PubMed] 
32. Su, H.; Bodenstein, C.; Dumont, R.A.; Seimbille, Y.; Dubinett, S.; Phelps, M.E.; Herschman, H.; Czernin, J.; Weber, W. Monitoring tumor glucose utilization by positron emission tomography for the prediction of treatment response to epidermal growth factor receptor kinase inhibitors. Clin. Cancer Res. 2006, 12, 5659-5667. [CrossRef] [PubMed]

33. Aukema, T.S.; Kappers, I.; Olmos, R.A.; Codrington, H.E.; van Tinteren, H.; van Pel, R.; Klomp, H.M.; NEL Study Group. Is ${ }^{18}$ F-FDG PET/CT useful for the early prediction of histopathologic response to neoadjuvant erlotinib in patients with non-small cell lung cancer? J. Nucl. Med. 2010, 51, 1344-1348. [CrossRef]

34. Benz, M.R.; Herrmann, K.; Walter, F.; Garon, E.B.; Reckamp, K.L.; Figlin, R.; Phelps, M.E.; Weber, W.A.; Czernin, J.; Allen-Auerbach, M.S. (18)F-FDG PET/CT for monitoring treatment responses to the epidermal growth factor receptor inhibitor erlotinib. J. Nucl. Med. 2011, 52, 1684-1689. [CrossRef] [PubMed]

35. Sung, P.S.; Park, H.L.; Yang, K.; Hwang, S.; Song, M.J.; Jang, J.W.; Choi, Y.W.; Yoon, S.K.; Yoo, I.R.; Bae, S.H. ${ }^{18} \mathrm{~F}$-fluorodeoxyglucose uptake of hepatocellular carcinoma as a prognostic predictor in patients with sorafenib treatment. Eur. J. Nucl. Med. Mol. Imaging 2018, 45, 384-391. [CrossRef] [PubMed]

36. Ma, W.W.; Jacene, H.; Song, D.; Vilardell, F.; Messersmith, W.A.; Laheru, D.; Wahl, R.; Endres, C.; Jimeno, A.; Pomper, M.G.; et al. $\left[{ }^{18} \mathrm{~F}\right]$ fluorodeoxyglucose positron emission tomography correlates with Akt pathway activity but is not predictive of clinical outcome during mTOR inhibitor therapy. J. Clin. Oncol. 2009, 27, 2697-2704. [CrossRef]

37. Beaver, J.A.; Hazarika, M.; Mulkey, F.; Mushti, S.; Chen, H.; He, K.; Sridhara, R.; Goldberg, K.B.; Chuk, M.K.; Chi, D.; et al. Patients with melanoma treated with an anti-PD-1 antibody beyond RECIST progression: A US Food and Drug Administration pooled analysis. Lancet Oncol. 2018, 19, 229-239. [CrossRef]

38. Pardoll, D.M. The blockade of immune checkpoints in cancer immunotherapy. Nat. Rev. Cancer 2012, 12, 252-264. [CrossRef]

39. Walunas, T.L.; Lenschow, D.J.; Bakker, C.Y.; Linsley, P.S.; Freeman, G.J.; Green, J.M.; Thompson, C.B.; Bluestone, J.A. CTLA-4 can function as a negative regulator of T cell activation. Immunity 1994, 1, 405-413. [CrossRef]

40. Giri, A.; Walia, S.S.; Gajra, A. Clinical Trials Investigating Immune Checkpoint Inhibitors in Non-Small-Cell Lung Cancer. Rev. Recent Clin. Trials. 2016, 11, 297-305. [CrossRef]

41. Ball, M.W.; Allaf, M.E.; Drake, C.G. Recent advances in immunotherapy for kidney cancer. Discov. Med. 2016, 21, 305-313.

42. Younes, A.; Santoro, A.; Shipp, M.; Zinzani, P.L.; Timmerman, J.M.; Ansell, S.; Armand, P.; Fanale, M.; Ratanatharathorn, V.; Kuruvilla, J.; et al. Nivolumab for classical Hodgkin's lymphoma after failure of both autologous stem-cell transplantation and brentuximab vedotin: A multicentre, multicohort, single-arm phase 2 trial. Lancet Oncol. 2016, 17, 1283-1294. [CrossRef]

43. Aide, N.; Hicks, R.J.; Le Tourneau, C.; Lheureux, S.; Fanti, S.; Lopci, E. FDG PET/CT for assessing tumour response to immunotherapy: Report on the EANM symposium on immune modulation and recent review of the literature. Eur. J. Nucl. Med. Mol. Imaging 2019, 46, 238-250. [CrossRef] [PubMed]

44. Lheureux, S.; Denoyelle, C.; Ohashi, P.S.; De Bono, J.S.; Mottaghy, F.M. Molecularly targeted therapies in cancer: A guide for the nuclear medicine physician. Eur. J. Nucl. Med. Mol. Imaging 2017, 44, 41-54. [CrossRef] [PubMed]

45. Kaira, K.; Higuchi, T.; Naruse, I.; Arisaka, Y.; Tokue, A.; Altan, B.; Suda, S.; Mogi, A.; Shimizu, K.; Sunaga, N.; et al. Metabolic activity by ${ }^{18} \mathrm{~F}-\mathrm{FDG}-\mathrm{PET} / \mathrm{CT}$ is predictive of early response after nivolumab in previously treated NSCLC. Eur. J. Nucl. Med. Mol. Imaging 2018, 45, 56-66. [CrossRef] [PubMed]

46. Cho, S.Y.; Lipson, E.J.; Im, H.J.; Rowe, S.P.; Gonzalez, E.M.; Blackford, A.; Chirindel, A.; Pardoll, D.M.; Topalian, S.L.; Wahl, R.L. Prediction of Response to Immune Checkpoint Inhibitor Therapy Using Early-Time-Point ${ }^{18}$ F-FDG PET/CT Imaging in Patients with Advanced Melanoma. J. Nucl. Med. 2017, 58, 1421-1428. [CrossRef]

47. Sachpekidis, C.; Larribere, L.; Pan, L.; Haberkorn, U.; Dimitrakopoulou-Strauss, A.; Hassel, J.C. Predictive value of early ${ }^{18} \mathrm{~F}$-FDG PET/CT studies for treatment response evaluation to ipilimumab in metastatic melanoma: Preliminary results of an ongoing study. Eur. J. Nucl. Med. Mol. Imaging 2015, 42, 386-396. [CrossRef]

48. Kong, B.Y.; Menzies, A.M.; Saunders, C.A.; Liniker, E.; Ramanujam, S.; Guminski, A.; Kefford, R.F.; Long, G.V.; Carlino, M.S. Residual FDG-PET metabolic activity in metastatic melanoma patients with prolonged response to anti-PD-1 therapy. Pigment Cell Melanoma Res. 2016, 29, 572-577. [CrossRef] 
49. Dercle, L.; Ammari, S.; Seban, R.D.; Schwartz, L.H.; Houot, R.; Labaied, N.; Mokrane, F.Z.; Lazarovici, J.; Danu, A.; Marabelle, A. Kinetics and nadir of responses to immune checkpoint blockade by anti-PD1 in patients with classical Hodgkin lymphoma. Eur. J. Cancer 2018, 91, 136-144. [CrossRef]

50. Ito, K.; Teng, R.; Schöder, H.; Humm, J.L.; Ni, A.; Michaud, L.; Nakajima, R.; Yamashita, R.; Wolchok, J.D.; Weber, W.A. ${ }^{18}$ F-FDG PET/CT for Monitoring of Ipilimumab Therapy in Patients with Metastatic Melanoma. J. Nucl. Med. 2019, 60, 335-341. [CrossRef]

51. Rossi, G.; Bauckneht, M.; Genova, C.; Rijavec, E.; Biello, F.; Mennella, S.; Dal Bello, M.G.; Cittadini, G.; Bruzzi, P.; Piva, R.; et al. Comparison between ${ }^{18}$ F-FDG-PET- and CT-based criteria in non-small cell lung cancer (NSCLC) patients treated with Nivolumab [published online ahead of print, 2019 Dec 5]. J. Nucl. Med. 2020, 61, 990-998. [CrossRef] [PubMed]

52. Lopci, E.; Meignan, M. Current Evidence on PET Response Assessment to Immunotherapy in Lymphomas. PET Clin. 2020, 15, 23-34. [CrossRef] [PubMed]

53. Nobashi, T.; Baratto, L.; Reddy, S.A.; Srinivas, S.; Toriihara, A.; Hatami, N.; Yohannan, T.K.; Mittra, E. Predicting Response to Immunotherapy by Evaluating Tumors, Lymphoid Cell-Rich Organs, and Immune-Related Adverse Events Using FDG-PET/CT. Clin. Nucl. Med. 2019, 44, e272-e279. [CrossRef] [PubMed]

54. Mekki, A.; Dercle, L.; Lichtenstein, P.; Marabelle, A.; Michot, J.M.; Lambotte, O.; Le Pavec, J.; De Martin, E.; Balleyguier, C.; Champiat, S.; et al. Detection of immune-related adverse events by medical imaging in patients treated with anti-programmed cell death 1. Eur. J. Cancer 2018, 96, 91-104. [CrossRef] [PubMed]

55. Pektor, S.; Hilscher, L.; Walzer, K.C.; Miederer, I.; Bausbacher, N.; Loquai, C.; Schreckenberger, M.; Sahin, U.; Diken, M.; Miederer, M. In vivo imaging of the immune response upon systemic RNA cancer vaccination by FDG-PET. EJNMMI Res. 2018, 8, 80. [CrossRef] [PubMed]

56. Decazes, P.; Bohn, P. Immunotherapy by Immune Checkpoint Inhibitors and Nuclear Medicine Imaging: Current and Future Applications. Cancers 2020, 12, 371. [CrossRef] [PubMed]

57. Tan, A.C.; Emmett, L.; Lo, S.; Liu, V.; Kapoor, R.; Carlino, M.S.; Guminski, A.D.; Long, G.V.; Menzies, A.M. FDG-PET response and outcome from anti-PD-1 therapy in metastatic melanoma. Ann. Oncol. 2018, 29, 2115-2120. [CrossRef]

58. Jreige, M.; Letovanec, I.; Chaba, K.; Renaud, S.; Rusakiewicz, S.; Cristina, V.; Peters, S.; Krueger, T.; de Leval, L.; Kandalaft, L.E.; et al. ${ }^{18}$ F-FDG PET metabolic-to-morphological volume ratio predicts PD-L1 tumour expression and response to PD-1 blockade in non-small-cell lung cancer. Eur. J. Nucl. Med. Mol. Imaging 2019, 46, 1859-1868. [CrossRef]

59. Amrane, K.; Le Goupil, D.; Quere, G.; Delcroix, O.; Gouva, S.; Schick, U.; Salaun, P.Y.; Abgral, R.; Alavi, Z.; Keromnes, N.; et al. Prediction of response to immune checkpoint inhibitor therapy using ${ }^{18} \mathrm{~F}-\mathrm{FDG}$ PET/CT in patients with melanoma. Medicine 2019, 98, e16417. [CrossRef]

60. Castello, A.; Rossi, S.; Mazziotti, E.; Toschi, L.; Lopci, E. Hyperprogressive Disease in Patients with Non-Small Cell Lung Cancer Treated with Checkpoint Inhibitors: The Role of ${ }^{18}$ F-FDG PET/CT. J. Nucl. Med. 2020, 61, 821-826. [CrossRef]

61. Annovazzi, A.; Vari, S.; Giannarelli, D.; Pasqualoni, R.; Sciuto, R.; Carpano, S.; Cognetti, F.; Ferraresi, V. Comparison of ${ }^{18}$ F-FDG PET/CT Criteria for the Prediction of Therapy Response and Clinical Outcome in Patients With Metastatic Melanoma Treated With Ipilimumab and PD-1 Inhibitors. Clin. Nucl. Med. 2020, 45, 187-194. [CrossRef]

62. Castello, A.; Carbone, F.G.; Rossi, S.; Monterisi, S.; Federico, D.; Toschi, L.; Lopci, E. Circulating Tumor Cells and Metabolic Parameters in NSCLC Patients Treated with Checkpoint Inhibitors. Cancers 2020, 12, 487. [CrossRef] [PubMed]

63. Hashimoto, K.; Kaira, K.; Yamaguchi, O.; Mouri, A.; Shiono, A.; Miura, Y.; Murayama, Y.; Kobayashi, K.; Kagamu, H.; Kuji, I. Potential of FDG-PET as Prognostic Significance after anti-PD-1 Antibody against Patients with Previously Treated Non-Small Cell Lung Cancer. J. Clin. Med. 2020, 9, 725. [CrossRef] [PubMed]

64. Seban, R.D.; Moya-Plana, A.; Antonios, L.; Yeh, R.; Marabelle, A.; Deutsch, E.; Schwartz, L.H.; Herrera Gómez, R.G.; Saenger, Y.; Robert, C.; et al. Prognostic ${ }^{18}$ F-FDG PET biomarkers in metastatic mucosal and cutaneous melanoma treated with immune checkpoint inhibitors targeting PD-1 and CTLA-4. Eur. J. Nucl. Med. Mol. Imaging 2020. [CrossRef] [PubMed] 
65. Nakamoto, R.; Zaba, L.C.; Rosenberg, J.; Reddy, S.A.; Nobashi, T.W.; Davidzon, G.; Aparici, C.M.; Nguyen, J.; Moradi, F.; Iagaru, A.; et al. Prognostic value of volumetric PET parameters at early response evaluation in melanoma patients treated with immunotherapy. Eur. J. Nucl. Med. Mol. Imaging 2020. [CrossRef]

66. Iravani, A.; Osman, M.M.; Weppler, A.M.; Wallace, R.; Galligan, A.; Lasocki, A.; Hunter, M.O.; Akhurst, T.; Hofman, M.S.; Lau, P.; et al. FDG PET/CT for tumoral and systemic immune response monitoring of advanced melanoma during first-line combination ipilimumab and nivolumab treatment. Eur. J. Nucl. Med. Mol. Imaging 2020. [CrossRef]

67. Umeda, Y.; Morikawa, M.; Anzai, M.; Ameshima, S.; Kadowaki, M.; Waseda, Y.; Shigemi, H.; Tsujikawa, T.; Kiyono, Y.; Okazawa, H.; et al. Predictive value of integrated ${ }^{18}$ F-FDG PET/MRI in the early response to nivolumab in patients with previously treated non-small cell lung cancer. J. Immunother Cancer 2020, 8 , e000349. [CrossRef]

68. Castello, A.; Rossi, S.; Toschi, L.; Mansi, L.; Lopci, E. Soluble PD-L1 in NSCLC Patients Treated with Checkpoint Inhibitors and Its Correlation with Metabolic Parameters. Cancers 2020, 12, 1373. [CrossRef]

69. De Giorgi, U.; Caroli, P.; Scarpi, E.; Conteduca, V.; Burgio, S.L.; Menna, C.; Moretti, A.; Galassi, R.; Rossi, L.; Amadori, D.; et al. ${ }^{18} \mathrm{~F}$-Fluorocholine PET/CT for early response assessment in patients with metastatic castration-resistant prostate cancer treated with enzalutamide. Eur. J. Nucl. Med. Mol. Imaging 2015, 42, 1276-1283, Erratum in 2015, 42, 1337-1338. [CrossRef]

70. De Giorgi, U.; Caroli, P.; Burgio, S.L.; Menna, C.; Conteduca, V.; Bianchi, E.; Fabbri, F.; Carretta, E.; Amadori, D.; Paganelli, G.; et al. Early outcome prediction on ${ }^{18}$ F-fluorocholine PET/CT in metastatic castration-resistant prostate cancer patients treated with abiraterone. Oncotarget 2014, 5, 12448-12458. [CrossRef]

71. Maines, F.; Caffo, O.; Donner, D.; Sperduti, I.; Bria, E.; Veccia, A.; Chierichetti, F.; Tortora, G.; Galligioni, E. Serial ${ }^{18} \mathrm{~F}$-choline-PET imaging in patients receiving enzalutamide for metastatic castration-resistant prostate cancer: Response assessment and imaging biomarkers. Future Oncol. 2016, 12, 333-342. [CrossRef] [PubMed]

72. Middendorp, M.; Maute, L.; Sauter, B.; Vogl, T.J.; Grünwald, F. Initial experience with ${ }^{18}$ F-fluoroethylcholine $\mathrm{PET} / \mathrm{CT}$ in staging and monitoring therapy response of advanced renal cell carcinoma. Ann. Nucl. Med. 2010, 24, 441-446. [CrossRef] [PubMed]

73. Kitajima, K.; Yamamoto, S.; Nakanishi, Y.; Yamada, Y.; Hashimoto, T.; Suzuki, T.; Go, S.; Kanematsu, A.; Nojima, M.; Fujiwara, M.; et al. Evaluation of Treatment Response in Prostate Cancer and Renal Cell Carcinoma Patients Using 11C-choline PET/CT Findings. Acta. Med. Okayama 2019, 73, 341-347. [PubMed]

74. Fendler, W.P.; Eiber, M.; Beheshti, M.; Bomanji, J.; Ceci, F.; Cho, S.; Giesel, F.; Haberkorn, U.; Hope, T.A.; Kopka, K.; et al. ${ }^{68}$ Ga-PSMA PET/CT: Joint EANM and SNMMI procedure guideline for prostate cancer imaging: Version 1.0. Eur. J. Nucl. Med. Mol. Imaging 2017, 44, 1014-1024. [CrossRef] [PubMed]

75. Dorff, T.B.; Fanti, S.; Farolfi, A.; Reiter, R.E.; Sadun, T.Y.; Sartor, O. The Evolving Role of Prostate-Specific Membrane Antigen-Based Diagnostics and Therapeutics in Prostate Cancer. Am. Soc. Clin. Oncol. Educ. Book 2019, 39, 321-330. [CrossRef] [PubMed]

76. Ceci, F.; Castellucci, P.; Fanti, S. Current application and future perspectives of prostate specific membrane antigen PET imaging in prostate cancer. Q. J. Nucl. Med. Mol. Imaging 2019, 63, 7-18. [CrossRef]

77. Bostwick, D.G.; Pacelli, A.; Blute, M.; Roche, P.; Murphy, G.P. Prostate specific membrane antigen expression in prostatic intraepithelial neoplasia and adenocarcinoma: A study of 184 cases. Cancer 1998, 82, 2256-2261. [CrossRef]

78. Pillai, A.M.; Knapp, F.F., Jr. Lutetium-177 Labeled Therapeutics: ${ }^{177}$ Lu-PSMA is Set to Redefine Prostate Cancer Treatment. Curr. Radiopharm. 2016, 9, 6-7. [CrossRef]

79. Emmett, L.; Crumbaker, M.; Ho, B.; Willowson, K.; Eu, P.; Ratnayake, L.; Epstein, R.; Blanksby, A.; Horvath, L.; Guminski, A.; et al. Results of a Prospective Phase 2 Pilot Trial of ${ }^{177}$ Lu-PSMA-617 Therapy for Metastatic Castration-Resistant Prostate Cancer Including Imaging Predictors of Treatment Response and Patterns of Progression. Clin. Genitourin. Cancer 2019, 17, 15-22. [CrossRef]

80. Bozkurt, M.F.; Virgolini, I.; Balogova, S.; Beheshti, M.; Rubello, D.; Decristoforo, C.; Ambrosini, V.; Kjaer, A.; Delgado-Bolton, R.; Kunikowska, J.; et al. Guideline for PET/CT imaging of neuroendocrine neoplasms with ${ }^{68}$ Ga-DOTA-conjugated somatostatin receptor targeting peptides and ${ }^{18}$ F-DOPA. Eur. J. Nucl. Med. Mol. Imaging 2017, 44, 1588-1601, Erratum in 2017, 44, 2150-2151. [CrossRef] 
81. Bodei, L.; Mueller-Brand, J.; Baum, R.P.; Pavel, M.E.; Hörsch, D.; O’Dorisio, M.S.; O’Dorisio, T.S.; Howe, J.R.; Cremonesi, M.; Kwekkeboom, D.J.; et al. The joint IAEA, EANM, and SNMMI practical guidance on peptide receptor radionuclide therapy (PRRNT) in neuroendocrine tumours. Eur. J. Nucl. Med. Mol. Imaging 2013, 40, 800-816, Erratum in O'Dorisio, T.M. Eur. J. Nucl. Med. Mol. Imaging 2014, 41, 584. [CrossRef]

82. Hope, T.A.; Bergsland, E.K.; Bozkurt, M.F.; Graham, M.; Heaney, A.P.; Herrmann, K.; Howe, J.R.; Kulke, M.H.; Kunz, P.L.; Mailman, J.; et al. Appropriate Use Criteria for Somatostatin Receptor PET Imaging in Neuroendocrine Tumors. J. Nucl. Med. 2018, 59, 66-74. [CrossRef] [PubMed]

83. Mammatas, L.H.; Venema, C.M.; Schröder, C.P.; de Vet, H.C.W.; van Kruchten, M.; Glaudemans, A.W.J.M.; Yaqub, M.M.; Verheul, H.M.W.; Boven, E.; van der Vegt, B.; et al. Visual and quantitative evaluation of $\left[{ }^{18} \mathrm{~F}\right] \mathrm{FES}$ and $\left[{ }^{18} \mathrm{~F}\right] \mathrm{FDHT}$ PET in patients with metastatic breast cancer: An interobserver variability study. EJNMMI Res. 2020, 10, 40. [CrossRef] [PubMed]

84. Venema, C.M.; Mammatas, L.H.; Schröder, C.P.; van Kruchten, M.; Apollonio, G.; Glaudemans, A.W.J.M.; Bongaerts, A.H.H.; Hoekstra, O.S.; Verheul, H.M.W.; Boven, E.; et al. Androgen and Estrogen Receptor Imaging in Metastatic Breast Cancer Patients as a Surrogate for Tissue Biopsies. J. Nucl. Med. 2017, 58, 1906-1912. [CrossRef] [PubMed]

85. Chae, S.Y.; Ahn, S.H.; Kim, S.B.; Han, S.; Lee, S.H.; Oh, S.J.; Lee, S.J.; Kim, H.J.; Ko, B.S.; Lee, J.W.; et al. Diagnostic accuracy and safety of $16 \alpha-\left[{ }^{18} \mathrm{~F}\right]$ fluoro- $17 \beta$-oestradiol PET-CT for the assessment of oestrogen receptor status in recurrent or metastatic lesions in patients with breast cancer: A prospective cohort study. Lancet Oncol. 2019, 20, 546-555. [CrossRef]

86. Katzenellenbogen, J.A. The quest for improving the management of breast cancer by functional imaging: The discovery and development of $16 \alpha-\left[{ }^{18} \mathrm{~F}\right]$ fluoroestradiol (FES), a PET radiotracer for the estrogen receptor, a historical review. Nucl. Med. Biol. 2020. [CrossRef]

87. Kurland, B.F.; Peterson, L.M.; Lee, J.H.; Linden, H.M.; Schubert, E.K.; Dunnwald, L.K.; Link, J.M.; Krohn, K.A.; Mankoff, D.A. Between-patient and within-patient (site-to-site) variability in estrogen receptor binding, measured in vivo by ${ }^{18}$ F-fluoroestradiol PET. J. Nucl. Med. 2011, 52, 1541-1549. [CrossRef]

88. Nienhuis, H.H.; van Kruchten, M.; Elias, S.G.; Glaudemans, A.W.J.M.; de Vries, E.F.J.; Bongaerts, A.H.H.; Schröder, C.P.; de Vries, E.G.E.; Hospers, G.A.P. ${ }^{18}$ F-Fluoroestradiol Tumor Uptake Is Heterogeneous and Influenced by Site of Metastasis in Breast Cancer Patients. J. Nucl. Med. 2018, 59, 1212-1218. [CrossRef]

89. Mortimer, J.E.; Dehdashti, F.; Siegel, B.A.; Katzenellenbogen, J.A.; Fracasso, P.; Welch, M.J. Positron emission tomography with 2-[ $\left.{ }^{18} \mathrm{~F}\right]$ Fluoro-2-deoxy-D-glucose and 16alpha- $\left[{ }^{18} \mathrm{~F}\right]$ fluoro-17beta-estradiol in breast cancer: Correlation with estrogen receptor status and response to systemic therapy. Clin. Cancer Res. 1996, 2, 933-939.

90. Van Kruchten, M.; de Vries, E.G.; Glaudemans, A.W.; van Lanschot, M.C.; van Faassen, M.; Kema, I.P.; Brown, M.; Schröder, C.P.; de Vries, E.F.; Hospers, G.A. Measuring residual estrogen receptor availability during fulvestrant therapy in patients with metastatic breast cancer. Cancer Discov. 2015, 5, 72-81. [CrossRef]

91. Scher, H.I.; Beer, T.M.; Higano, C.S.; Anand, A.; Taplin, M.E.; Efstathiou, E.; Rathkopf, D.; Shelkey, J.; Yu, E.Y.; Alumkal, J.; et al. Antitumour activity of MDV3100 in castration-resistant prostate cancer: A phase 1-2 study. Lancet 2010, 375, 1437-1446. [CrossRef]

92. Linden, H.M.; Kurland, B.F.; Peterson, L.M.; Schubert, E.K.; Gralow, J.R.; Specht, J.M.; Ellis, G.K.; Lawton, T.J.; Livingston, R.B.; Petra, P.H. Fluoroestradiol positron emission tomography reveals differences in pharmacodynamics of aromatase inhibitors, tamoxifen, and fulvestrant in patients with metastatic breast cancer. Clin. Cancer Res. 2011, 17, 4799-4805. [CrossRef] [PubMed]

93. Bensch, F.; van der Veen, E.L.; Lub-de Hooge, M.N.; Jorritsma-Smit, A.; Boellaard, R.; Kok, I.C.; Oosting, S.F.; Schröder, C.P.; Hiltermann, T.J.N.; van der Wekken, A.J.; et al. ${ }^{89} \mathrm{Zr}$-atezolizumab imaging as a non-invasive approach to assess clinical response to PD-L1 blockade in cancer. Nat. Med. 2018, 24, 1852-1858. [CrossRef] [PubMed]

94. Niemeijer, A.N.; Leung, D.; Huisman, M.C.; Bahce, I.; Hoekstra, O.S.; van Dongen, G.A.M.S.; Boellaard, R.; Du, S.; Hayes, W.; Smith, R.; et al. Whole body PD-1 and PD-L1 positron emission tomography in patients with non-small-cell lung cancer. Nat. Commun. 2018, 9, 4664. [CrossRef] [PubMed]

(C) 2020 by the authors. Licensee MDPI, Basel, Switzerland. This article is an open access article distributed under the terms and conditions of the Creative Commons Attribution (CC BY) license (http://creativecommons.org/licenses/by/4.0/). 